IZA DP No. 8106

Remittances and Household Expenditure Behaviour in Senegal

Teresa Randazzo

Matloob Piracha

April 2014 


\title{
Remittances and Household Expenditure Behaviour in Senegal
}

\author{
Teresa Randazzo \\ University of Kent
}

\author{
Matloob Piracha \\ University of Kent \\ and IZA
}

\section{Discussion Paper No. 8106 \\ April 2014}

IZA

P.O. Box 7240

53072 Bonn

Germany

\author{
Phone: +49-228-3894-0 \\ Fax: +49-228-3894-180 \\ E-mail: iza@iza.org
}

\begin{abstract}
Any opinions expressed here are those of the author(s) and not those of IZA. Research published in this series may include views on policy, but the institute itself takes no institutional policy positions. The IZA research network is committed to the IZA Guiding Principles of Research Integrity.

The Institute for the Study of Labor (IZA) in Bonn is a local and virtual international research center and a place of communication between science, politics and business. IZA is an independent nonprofit organization supported by Deutsche Post Foundation. The center is associated with the University of Bonn and offers a stimulating research environment through its international network, workshops and conferences, data service, project support, research visits and doctoral program. IZA engages in (i) original and internationally competitive research in all fields of labor economics, (ii) development of policy concepts, and (iii) dissemination of research results and concepts to the interested public.
\end{abstract}

IZA Discussion Papers often represent preliminary work and are circulated to encourage discussion. Citation of such a paper should account for its provisional character. A revised version may be available directly from the author. 
IZA Discussion Paper No. 8106

April 2014

\section{ABSTRACT}

\section{Remittances and Household Expenditure Behaviour in Senegal ${ }^{*}$}

This paper analyses the impact of remittances on household expenditure behaviour in Senegal. We use propensity score matching and OLS methods to assess the average impact of remittances on several household budget shares. Our results show a productive use of international remittances in Senegal. However, the impact of remittances disappears when the marginal spending behaviour is considered, i.e., households do not show a different consumption pattern with respect to their remittance status. Therefore, in the decision on how to allocate expenditure, remittances are treated just as any other source of income.

JEL Classification: F24, O12, O15

Keywords: remittances, household expenditure, Senegal

Corresponding author:

Matloob Piracha

School of Economics

Keynes College

University of Kent

Canterbury, Kent CT2 7NP

United Kingdom

E-mail: m.e.piracha@kent.ac.uk

*We would like to thank Sylvain Barde for helpful comments. 


\section{Introduction}

Remittances are one of the key factors in understanding the effect of migration on the countries of origin. There is a growing interest on how remittances are spent and whether their use impacts the economic development (Adams and Cuecuecha, 2010a; 2010b). The role that remittances can play, at the household level and the consequent effects on the local community, depend on how remittances are perceived by the household. The literature presents three views. The first view, which is part of the permanent income hypothesis, is that remittances are transitory income and therefore are spent, at the margin, in more 'productive' activities like human and physical capitals. If this is the case then remittances should have a long term impact on growth and development of the receiving country. The second view is that remittances are compensatory income and therefore spent more on consumption rather than investment goods. While this could result in generating domestic production perhaps, it can also lead to an indirect effect on inflation in a number of developing countries (Narayan et al., 2011). The final view regards remittances as just any other source of income and therefore no difference in the expenditure behaviour emerges from the households' remittance status.

The objective of this paper is to contribute and extend the debate on how remittances are spent or used by the recipient households. We conduct the analysis using migration and remittance data from a much neglected region in migration research, Africa. More precisely, we use the data from Senegal, which has recently become one of the leading out-migration (both internal and international) countries in sub-Saharan Africa. The survey data, collected in 2009, was part of the African Migration Project, led by the World Bank. The data allows us to differentiate four types of households: those who receive no remittances; remittance recipients from internal migration; remittance recipients from international migration; and finally households who receive remittances from both internal and international migrants. We consider recipient households according to the origin of remittances because we want to capture whether the source of transfers affects the household perception of remittances and therefore the way they use them. Several empirical studies find that domestic and international remittances affect differently the consumption behaviour of households on consumed and investment goods. For instance, Adams (1996) finds that internal remittances have an equalizing impact on income distribution while external remittances have the opposite effect (see also Clément, 2011; Adams and Cuecuecha, 2010b; Adams et al., 2008b; Castaldo and Reilly, 2007).

We assume that each household has to allocate its expenditure on several commodities and we want to understand whether receiving remittances have any impact on the household decision. We are able to identify seven types of goods: food, consumed and durable goods, housing and land, 
investment, education, other type of items such as expenditure on funerals, engagements and weddings. The analysis is conducted using different approaches and empirical methodologies to ensure robustness of the results. Our main objective is to determine how remittances impact expenditure behaviour at the margin. In order to assess that, we use the popular Working-Leser model which relates budget shares linearly to the logarithm of total household expenditure. For the Working-Leser model we need to carry out the estimations using Ordinary Least Squares (OLS). However, given that recipient households are not randomly selected, characteristics associated with a particular household rather than their status of being a remittance recipient can potentially have an impact on their expenditure behaviour, which means OLS results could be biased. As we could not find a suitable instrument in the data to correct the bias, we first apply propensity score matching analysis to evaluate the impact of receiving a "treatment" - represented by the different sources of remittances - on household expenditure behaviour. Five matching methods are compared in order to assess the impact of remittances on expenditure choice. Our results show that domestic transfers do not have a strong impact on household expenditure decision whereas international remittances have a significant negative impact on the expenditure on food and a positive impact on durables, investment and education. It therefore seems that international remittances result in investment in productive elements like human capital and not spent on consumption.

Propensity score matching (PSM) only helps us evaluate the impact of remittances at the average level of each budget share but not at how they are spent at the margin. However, the PSM results provide us with a benchmark against which the robustness of the OLS estimates of marginal budget shares and elasticities for different types of goods could be assessed. We obtain similar insights of the impact of remittances on household budget shares when comparing the OLS outcomes with the PSM estimates. This shows that OLS results do not suffer from selection bias. We then explore household consumption decision looking at marginal behaviour and do not find any significant difference in how households allocate their marginal expenditure. Moreover, looking at the demand elasticities, it is clear that the different types of recipient households perceive expenditure items in quite a similar way, i.e. in terms of necessity, normal or luxury goods. The demand elasticities and marginal consumption results show that remittances do not change the household expenditure behaviour, i.e., remittances are treated just like other income.

The rest of the paper is structured as follows. Section 2 contains a brief outlook on Senegal and its emergence as an important emigration country while section 3 presents the relevant literature on the relation between remittances and household consumption patterns. Section 4 describes the dataset used in this study; section 5 presents the propensity score matching techniques 
and the Working-Leser model. Section 6 discusses and compares the empirical findings and the last section 7 concludes the paper.

\section{Senegal: A Brief Background}

Sub-Saharan Africa (SSA) has evolved into an important emigration region. In the recent years the rate of migration from the SSA has increased dramatically. For instance, between 2000 and 2005 the outward migration increased by $275 \%$ (Naudé, 2010). The recent highest growth rate in net migration is due to the interplay of different factors: political and economic instabilities, violent conflicts, climate change and deterioration of the environment which include desertification and rainfall related problems.

In comparison to the neighbouring states, Senegal is a country that experiences a good level of freedom and democracy both in political institutions and society; though an exception to the overall stability is represented by the Casamance conflict in the South of the country during the 1980s. The conflict led to intense refugee outflows due to human right abuses. Also, Senegal has experienced a number of social, economic and political crises: the devaluation of the Franc CFA in $1994^{1}$ and the high level of unemployment in the same period are expressions of the difficulties faced by the country. Moreover, at the beginning of 2000s poverty affected almost half of the population (Cisse, 2011).

Several rainfall shocks have occurred in the whole sahelian region in the past 50 years. The drought in the 1970s and 1980s was devastating for the economy as well as for the population in that area causing people to move within and beyond the borders. Even though there was a slight improvement in rainfall during the 1990s, a severe rainfall deficit occurred again in 2002 (Sarr, 2007) and the prospects for the future do not seem encouraging.

Senegal experiences both internal and external migration. Internal movements, especially from rural to urban regions are the predominant form of migration. Shortage of food in the rural areas, adverse climate conditions and the search of economic and employment opportunities explain internal migration which involves around 13 per cent of the Senegalese population with Dakar, Thies and Diourbel as the primary regions of destination (ANSD: RGPH- III, 2002). In terms of external migration, approximately 5 per cent of the population resides outside Senegal. West African countries are the principal destinations, attracting 53.4 per cent of Senegalese migrants. In Europe, France is the first preferred destination followed by Italy, Spain and Germany. But also USA is becoming an important transnational destination.

\footnotetext{
${ }^{1} 50$ per cent devaluation of the CFA franc against the French franc.
} 
As a consequence of the migration trends within and outside the country, the volume of workers' remittances to Senegal has increased considerably in the last decade. The real size of those transfers is unknown because of the different informal channels ${ }^{2}$ used to send them to the family left behind. The available official figures show that remittances quadrupled in less than a decade: from $\$ 305$ million to $\$ 1,288$ million between 2001 and 2008. The global financial crisis in 2009 slightly affected those monetary flows resulting in a decline of 8 percentage points. Nevertheless, migrants' transfers accounted for 9 per cent of GDP in 2009 compared to 6 per cent in 2001. A survey conducted in 2007 by the African Development Bank, which covers both formal and informal transfers, estimates that remittances to Senegal accounted for 19 per cent of the GDP in 2009. The larger proportion of transfers are generated in the European Union (52 per cent) mostly from Italy, Spain and France (Cisse, 2011)

Regular remittances are a new phenomenon and more and more households, especially in the rural areas, depend on those transfers to satisfy various daily needs. The second Senegalese Household Survey (ANSD: ESAM II, 2004) shows that the funds received from abroad have increased the average per capita expenditure of recipient households by almost 60 per cent compared to those households who do not receive remittances. It seems that the larger proportion of remittances goes to current consumption (Cisse, 2011; Some, 2009); and at the national level those transfers have reduced poverty by almost one-third (ANSD: ESAM II, 2004).

\section{Literature Review}

The household is the first unit which takes decision on the use of remittances and therefore, in essence, it determines the role remittances play in the development process of the receiving country. Remittances are received under imperfect information, uncertainty and with different regularity (Seshan, 2012; Chami et al., 2005), therefore how they are perceived by the households is not straightforward. Based on the previous empirical studies, the impact of remittances on household expenditure decision has been interpreted mainly according to three different views, discussed in Introduction above, which show that it is how the household perceives these transfers that determines how their use ends up in more or less productive activities. Recent studies interpret remittances as a transitory income and conclude for a positive effect of remittances on different types of goods: investment, housing, education and health.

For example, Edwards and Ureta (2003) analyse how different types of income remittances and income from other sources - affect the household decision on children's schooling level in El Salvador. They use a 1997 household survey of 14,286 individuals between the ages of

\footnotetext{
${ }^{2}$ Sending them through post, intermediaries or migrants carrying cash themselves.
} 
6 and 24 and conclude that the source of income does matter in the household decision for the investment in schooling: remittances have a larger positive effect on school retention both in urban and rural areas, even if the impact is stronger in the urban places. A positive impact of remittances on child education is also supported by Kifle (2007) in the case of Eritrea. He used 125 remittance receiving households with young members between 7 and 20 years old and found that recipient households spend a significant proportion of remittances on child education. These results are in contrast with the empirical evidence from Albania proposed by Cattaneo (2012) who shows that remittances do not influence spending on education.

Using data from the Philippines, Yang (2008) examines how household expenditure behaviour responds to a favourable exchange rate shock when international remittances are received. In particular, the paper looks at the expenditure patterns of 1646 households before and after the 1997 Asian financial crisis. Receiving more remittance income is associated with a positive effect on the ownership of various types of durable goods, hours worked in selfemployment and investment in the capital-intensive enterprises like transportation, communication and manufacturing. Most likely the exchange rate shock relaxed the credit constraints faced by the households providing them with the necessary resources to start new business activities. The access to international remittances helps overcome credit constraints in Woodruff and Zenteno's (2004) paper also. They find that remittances are responsible for more than 25 per cent of all capital invested in small micro-enterprises in rural Mexico. That percentage increases to 40 per cent within those regions with higher level of migration.

In a study based in 14 states in Mexico, Taylor and Mora (2006) control for different migrant destinations and therefore for potentially different sources of remittances. The main focus of their work is to look at the household marginal spending behaviour among three different types of households: those without migrants, those with internal migrants and finally the households with international migrants. They find differences in the expenditure behaviour among the three types of households. In particular, compared to non-migrant households, those with international migrants show a considerably large marginal spending for investment while those with internal migrants spend more on services, health and housing. Their findings support the view of a productive use of remittances. The same conclusion is reached by Adams and Cuecuecha (2010a) who also take into account different sources of remittances. Using a nationally-representative household survey in Guatemala, they find that at the margin both households receiving internal and external remittances spend more on human capital and investment goods - like education and housing - and less on food.

A more pessimistic view on how remittances are spent at the household level argues that transfers are used more on consumption rather than investment goods and they do not have any 
positive effect on development. This conclusion is strongly supported by Chami et al. (2005) who define remittances as compensatory transfers for poor economic performance. ${ }^{3}$ They construct a dataset including 113 countries over the period 1970-1998. Their empirical analysis reveals that remittances are negatively correlated with GDP growth and therefore those flows of money do not appear to be a source for economic development but rather may cause some behavioural changes at the household level: recipients reduce their labour supply and labour market participation. In another paper, Adams and Cuecuecha (2010b) find that in Indonesia remittances affect positively the marginal expenditure on one key consumption good - food - while the marginal expenditure on housing, considered an investment good, is reduced after remittance receipt. This finding contradicts what the same authors find in the similar study on Guatemala. They justify it with the different amount of transfers that the households in the two countries receive: the level of remittances received by the Guatemalan households is higher than those in Indonesia and the recipient in the latter case are much poorer. Therefore, while in Guatemala households are able to devote more of their marginal expenditure to investment goods, in Indonesia remittances are used to improve consumption in basic goods. Finally, Clément (2011) supports the idea that remittances are not used in a productive way. He shows that in Tajikistan international remittances significantly increase the household consumption level but have a negative impact on investment expenditures. However, the effect of domestic remittances is not clear, as they affect two investment goods in opposite directions: domestic transfers reduce expenditure on housing and agriculture but increase spending on health. No effect of remittances is found on other key investment variables such as education. He justifies this finding with the fact that health outcome is a short-term priority while education and agriculture represent long-term investments. He concludes that domestic remittances help households to achieve a basic level of consumption.

Another way to look at remittances is to consider them fungible and therefore just as any other source of income. If a euro of income of remittances is treated by the household as a euro of wage income then migrant's transfers do not produce any change in how the household allocate its expenditure. A number of empirical studies show that remittances do not have a differentiated impact on household expenditure behaviour, concluding that income is just income wherever it is generated. For example, Adams et al. (2008a) arrive at the same conclusion in their comparative study on household marginal spending behaviour in Ghana. Using the 2005/2006 Ghana Living Standards Survey, they investigate on a wide range of consumption and investment goods to capture any significant effect of remittances on household expenditure decision but it seems that remittance

\footnotetext{
${ }^{3}$ However, their empirical approach was challenged by Catrinescu et al. (2009) who, using the same data as Chami et al. (2005), showed that omitted variable bias was partially responsible for their results. In particular, controlling for political institutions in the receiving country, Catrinescu et al. showed a positive effect of remittances on investment and therefore on GDP growth.
} 
income is treated just like any other source of income. Similar results are obtained by Castaldo and Reilly (2007) for Albania and Ang et al. (2009) for the Philippines. However, Tabuga (2007) using the Philippines data finds mixed results. He shows that remittances are used for consumption purposes but they are also invested on education and housing.

A possible explanation for the existence of a wide range of empirical findings could be the difference in countries income level and perhaps in investment opportunities. It seems reasonable to think that remittances in middle-income countries are treated differently than in countries with a very low income level. In the latter case transfers are perhaps used as any other source of income without any behavioural change in the way in which households decide to allocate their expenditure.

\section{Data}

We investigate household expenditure behaviour using data from a recent Migration and Remittance Household Survey in Senegal. This survey is part of the African Migration Project (AMP) conducted in Sub-Saharan Africa by the African Development Bank and the World Bank during 2009 and 2010. The Africa Migration Survey defines migrant as "a person who used to live in a household in the country in which the interview is being conducted but left before the interview to live abroad, or in another village or urban area within the country, for at least six months." Remittances "include both international (cross-border) and national (within-country) person to person transfers of resources (both monetary and in-kind) often sent by migrant workers".

The questionnaire is structured in eight sections that altogether try to give a general view on characteristics of household members, household conditions and expenditures, migration motivations, migrant characteristics, remittances motives and information on return migrants. ${ }^{4}$ The survey is representative at the national level and 2,100 households were interviewed. We divide the sample into those who receive no remittances, remittance recipients from internal migration, remittance recipients from international migration and finally households who receive remittances from both internal and international migrants. The data file contains 1,953 households of which 713 are without any migrants, 523 have national migrants only, 561 have international migrants and 156 have both categories of migrants. Table 1 shows that, on average, the households with no migrants have the youngest household head and also a smaller household size compared to the migrant households. Looking at the level of education, households with international migrants have a higher percentage of members with secondary and tertiary education compared to households with national migrants. Non-migrant households have the highest proportion of members with tertiary education.

\footnotetext{
${ }^{4}$ A return migrant is defined as a person over 18 years old currently living in the household who had lived in another country or place for at least three months in the 5 years preceding the survey.
} 
As the focus of this study is on the impact of remittances on household expenditure behaviour, we classify households as receivers or non-receivers of remittances. Due to missing information in some of the considered expenditure categories we restrict the analysis to 1,939 households. This means that those households who have migrants but who do not receive remittances either from family or non-family members are recoded in the not receiving category together with the households with no migrants. Those households who do not have migrants but receive transfers from non-household members are included in one of the remittance-receiving categories, depending on where the remittances are generated. Finally, we end up with 948 households who do not receive remittances and 991 who receive transfers. Out of 991 in the latter category, 327 households receive transfers from within Senegal while 482 households receive international remittances; 182 households receive flows of money both from domestic and international destinations. Those receiving from both sources are considered in a separate category because we are not able to conclude which flow of money is predominant and the mixed effect does not allow us to interpret the household expenditure behaviour with respect to the place where remittances are generated. Moreover, we can interpret receiving remittances from multiple destinations as a family strategy to spread the risk between the home and the host countries.

We do not have any information on earnings therefore we are not able to attest in what percentage remittances contribute to household income. But in line with most demand studies we consider total expenditure instead of income (see Adams and Cuecuecha, 2010b; Adams et al., 2008a). Also household income can be measured with error whereas information on expenditure seems more reliable.

The survey collected detailed information on different types of household expenditure. We aggregate them considering the following categories: expenditure on food, consumed and durable goods, house and land, investment, education, health and other goods. The survey provides weekly and monthly expenditure on many commodities as well as for some types of items the information provided refers to the last six months. As the objective of this work is to understand the impact of remittances on household expenditure decision and the question on the amount of remittances received refers to the last year, we aggregate each type of expenditure to obtain annual values. Table 2 presents a description of what each category of expenditure contains; it also shows the overall average budget share of each group of commodities. Table 3 shows how much on average each type of household devotes to the different expenditures. It also includes a z-test performed to investigate whether differences in the means of the budget share devoted to a particular group of expenditure exist between households receiving and not receiving remittances. The reported pvalues indicate that the null hypothesis of equal means between households receiving internal 
remittances versus those who do not receive them has to be rejected for food and housing-land expenditures. In particular, household receiving domestic remittances spend 4 percentage points more on food and around 3 percentage points less on housing/land compared to those households without remittances. Differences also exist when we compare households receiving external remittances versus those who do not. Households receiving international remittances spend 4 percentage points less on food, 3 percentage points more on consumed and durables and almost 2 percentage points more on education. In the case of those households receiving remittances from multiple destinations, the z-test indicates that they spend 3 percentage points less on housing and land and almost 3 percentage points more on health compared to those who do not receive remittances.

\section{Methodology}

Our main objective is to estimate, using the well-known Working-Leser model, how remittances affect the expenditure behaviour at the margin. However, since the Working-Leser model uses OLS estimates, we need to first address the concern that those estimates may be biased due to endogeneity. An instrumental variable approach is generally used to deal with the endogeneity of the remittances variable. However, due to data limitation the identification of a suitable instrument is not possible in our case. We therefore employ the propensity score matching (PSM) as an alternative approach (see Clément, 2011; Equivel and Huerta-Pineda, 2007). If PSM and OLS estimators lead to similar results in terms of the impact of remittances on household budget shares then we can be confident on the good performance of the OLS method and conclude that it is not biased, i.e., that endogeneity is not an issue in our analysis.

The basic idea of the PSM is to estimate the average treatment effect related to the receipt of remittances on the outcome of interest. In particular, we compare the average expenditure behaviour of those households receiving remittances with those who do not receive remittances, matching the two groups of households according to similar characteristics. The difference in behaviour will then be attributed to the existence of remittances.

The treatment is expressed through a dummy variable $D_{j}$ equal to one if household $j$ receives remittances and zero if it does not. Let $Y_{i j 1}$ and $Y_{i j 0}$ indicate the outcome variables representing the budget share in good $i$ for household $j$ in the presence and absence of treatment, respectively. ${ }^{5}$ The treatment effect is the difference in the relevant outcome for unit $j$ between the situation in which the treatment occurs and the one in which it does not occur.

$$
\Delta Y_{j}=E\left(Y_{j 1} / D_{j}=1\right)-E\left(Y_{j 0} / D_{j}=1\right)_{j}
$$

${ }_{5} Y_{i j}=c_{i j} / \exp _{j}$; where $\mathrm{c}_{\mathrm{ij}}$ is the consumption in $\operatorname{good} i$ for family $j$ and $\exp _{\mathrm{j}}$ indicates the total household expenditure. 
The problem is that we do not observe the same unit under the two different states: we can estimate $\mathrm{E}\left(\mathrm{Y}_{j l} / \mathrm{D}_{j}=1\right)$ and $\mathrm{E}\left(\mathrm{Y}_{j 0} / \mathrm{D}_{\mathrm{j}}=0\right)$ but not their counterfactuals $\mathrm{E}\left(\mathrm{Y}_{j l} / \mathrm{D}_{j}=0\right)$ and $\mathrm{E}\left(\mathrm{Y}_{j 0} / \mathrm{D}_{j}=1\right)$. The propensity score matching represents a solution to the potential bias coming from the unobservability of the counterfactual outcomes.

The methodology consists in generating a single index value - the propensity score - which summarizes the pre-treatment characteristics of each subject and it makes possible the matching between those who receive the treatment and those who do not. The propensity score, which can be expressed as $\mathrm{P}(\mathrm{X})=\mathrm{P}\left(\mathrm{D}_{j}=1 / \mathrm{X}\right)$, represents the probability of receiving the treatment conditional on observed covariates. As suggested by Rosenbaum and Rubin $(1983,1985)$, the use of the propensity score reduces the dimensionality of the matching which becomes a problem when there are nvectors of covariates. The comparison between treated and not treated units, on the basis of observable characteristics, assumes that unobservables play no role in the assignment of the treatment (Dehejia and Wahba, 2002). The propensity score matching methods expect that given a set of observable variables $\mathrm{X}$, the outcome of interest is independent of the treatment participation. This condition is known as conditional independence assumption and it requires that only those covariates which are not affected by receiving remittances should be included in the model. This condition implies the absence of selection due to unobservable variables. The conditional independence assumption is expressed as:

$$
\left(Y_{j 0}, Y_{j 1}\right) \perp D_{j} / X_{j}
$$

A further requirement is the common support or overlap condition which states that individuals with the same characteristics have equal positive probability to receive or not the treatment.

$$
0<\left(D_{j}=1 / X_{j}\right)<1
$$

In other words, assumptions (2) and (3) ensure that the exposure to the treatment is random and therefore, on average, treated and control units should be identically observed. Following that it is possible to express the counterfactual as:

$$
E\left(Y_{j 0} / D_{j}=1, X_{j}\right)=E\left(Y_{j 0} / D_{j}=0, X_{j}\right)
$$


And finally, the PSM estimator for the average treatment effect on the treated (ATT) is simply "the mean difference in the outcomes over the common support, appropriately weighted by the propensity score distribution of participants" (Caliendo and Kopeining, 2008, p. 4):

$$
\Delta Y_{j}=E\left(Y_{j 1} / D_{j}=1, P\left(X_{j}\right)-E\left(Y_{j 0} / D_{j}=0, P\left(X_{j}\right)\right.\right.
$$

Given that the participation to the treatment is expressed as a dichotomous variable, the estimation of the propensity score over a set of covariates uses logit or probit models. The selection of a matching estimator, which follows, opens different matching options and we will present some of the most widely used methods in empirical studies. Overall, the matching estimators ensure that treated and comparison units with propensity score sufficiently close are matched.

The nearest neighbour consists in searching for each treated unit the closest control unit in term of propensity score. Then the difference for each pair of matched units is computed and the ATT is obtained as average of all these differences. We implement the method choosing the nonreplacement option instead of the one with replacement to avoid the possibility that the same comparison unit is used for several matches. ${ }^{6}$ The nearest five neighbours and the nearest ten neighbours are a generalization of this method allowing the use of five (ten) counterfactuals for each treated unit. The radius caliper estimator consists in matching each treated unit with those control units whose propensity score falls into a neighbourhood of the propensity score of the treated unit. The caliper defines the dimension of the neighbour (see Dehejia and Wahba, 2002); Following Clément (2011), we fix the caliper at 0.05. Finally, the kernel method matches each treated unit with a weighted average of all control units (Gaussian kernel).

Each of the methods introduced above presents advantages and drawbacks in terms of tradeoff between quality and quantity of the matches. Because none of them is superior to another and their performance depends on the data used in the research, their joint implementation can be used as robustness check. Moreover, in our study we conduct separate analysis with respect to the origin of remittances. Three mutually exclusive treatments can occur: receiving domestic remittances; receiving remittances from abroad; receiving remittances from both destinations. The households participating in one of these treatments are matched one at a time with those who do not receive remittances.

The propensity score matching methods estimate the average impact of receiving remittances on different household expenditures. That gives some insights into the role of remittances on the different types of consumption but unfortunately it does not allow to capture

\footnotetext{
${ }^{6}$ If replacement is chosen then the same comparison unit can be matched with more than one treated unit.
} 
whether relevant differences exist at the marginal expenditure behaviour among households receiving and not receiving remittances. The marginal budget shares can be easily calculated implementing the Working-Leser model with a simple OLS analysis.

First we need to be sure that the average effect of remittances on the household consumption pattern is in line with the results found applying the matching methods. The functional form for the budget share in good $i$ for household $j\left(\mathrm{Y}_{i j}\right)$ includes the same household characteristics $\mathrm{X}$ used to generate the propensity score in the matching process:

$$
Y_{i j}=\alpha_{i}+\gamma_{i} X_{j}+\theta_{i} D_{j}+u_{i j}
$$

where $u_{i j}$ is the idiosyncratic shock with mean zero and constant variance which captures the unknown variation in the $i^{\text {th }}$ budget share for the $j^{\text {th }}$ household. In this set-up, $D_{j}$ is a vector of mutually exclusive binary variables capturing whether or not the household $j$ receives remittances from one destination instead of another. ${ }^{7}$ Our exclusive dummy variables are: receiving domestic remittances only; receiving remittances from abroad only; receiving remittances from national and international destination; receiving no remittances. This last category represents the base group for the empirical analysis. We focus our attention on the estimates of $\theta_{i}$ vector which shows the effect of the different types of remittances on the relevant budget share and we compare those impacts with the results coming from the matching methods. If receiving remittances shows the same effect on the household budget share allocated to specific types of goods then the model presented in equation (6) can be extended to include the total household expenditure:

$$
Y_{i j}=\alpha_{i}+\beta_{i} \log \exp _{j}+\gamma_{i} X_{j}+\theta_{i} D_{j}+u_{i j}
$$

The functional form expressed in equation (7) is the Working-Leser Model which relates budget shares linearly to the logarithm of total household expenditure. ${ }^{8}$

As mentioned above, we are not only interested to have some insights on the role of remittances on the different types of consumption but our main attention goes to capture whether relevant differences exist in the marginal expenditure behaviour among households receiving and

\footnotetext{
${ }^{7}$ The use of binary measures for whether or not households receive remittances is a common approach followed by Zarate-Hoyos (2004), Castaldo and Reilly (2007), Adams and Cuecuecha (2010a). It is justified by the fact that monetary values for remittances may be affected by measurement errors.

8 The chosen functional form displays several advantages: it provides a good statistical fit to a wide range of commodities, the slope is free to change with the expenditure level and it conforms to the criterion of additivity $\left(\sum C_{i j} / \exp _{j}=1\right)$.
} 
not receiving remittances. The marginal budget share for good $i$ and household $j$ is defined as follows:

$$
m b s_{i j}=\frac{\partial c_{i j}}{\partial \exp _{j}}
$$

From equation (7), the partial derivative of the budget share with respect to the total consumption is given by:

$$
\frac{\partial Y_{i j}}{\partial \exp _{j}}=\frac{\exp _{j} \frac{\partial c_{i j}}{\partial \exp }-c_{i j} \frac{\partial \exp _{j}}{\partial \exp _{j}}}{\exp _{j}^{2}}=\frac{\beta_{i}}{\exp _{j}}
$$

Solving for $\frac{\partial c_{i j}}{\partial \exp _{j}}$ in equation (9) we find:

$$
m b s_{i j}=\beta_{i}+\frac{c_{i j}}{\exp _{j}}=\beta_{i}+Y_{i j}
$$

Eq. (10) can be calculated after estimating equation (7).

Using the definition of elasticity, the expenditure elasticity of good $i$ for household $j$ is given by the following expression:

$$
e_{i j}=\left(\beta_{i}+Y_{i j}\right) \frac{1}{Y_{i j}}=\frac{\beta_{i}}{Y_{i j}}+1
$$

In order to capture whether behavioural changes exist at the marginal level, we interact the $\log$ of total expenditure with the mutually exclusive dummy variables controlling for the different remittances status. The Working-Leser model expressed in equation (7) becomes:

$$
Y_{i j}=\alpha_{i}+\beta_{i} \log \exp _{j}+\gamma_{i} X_{j}+\theta_{i} D_{j}+\beta_{i}^{*} D_{j} \log \exp { }_{j}+u_{i j}
$$


Our focus here is on the vector $\beta_{i}^{* 9}$ which allows us to compute marginal budget shares and expenditure elasticities for the three household remittances status. In particular the marginal budget shares and demand elasticities for those who receive remittances (nationally, internationally or from both destinations) are:

$$
\begin{aligned}
& m b s_{i j}=\beta_{i}+\beta^{*}{ }_{i}+Y_{i j} \\
& e_{i j}=\frac{\beta_{i}+\beta_{i}^{*}}{Y_{i j}}+1
\end{aligned}
$$

Eqs (10) and (11) apply for those who do not receive remittances.

In modelling the impact of remittances on household expenditure we face some econometric issues. First, we find an important percentage of zeroes in some of the expenditure categories considered. ${ }^{10}$ The problem of zero expenditure is common in many household expenditure surveys. Zero observations may arise for mainly three reasons: non-consumption, the good is not affordable or infrequency of purchases. ${ }^{11} \mathrm{We}$ are not able to distinguish the behavioural from the random zeroes, which is why we do not address the problem of zero expenditure with a Tobit model.

Second, remittances may be endogenous reflecting migrant's earnings and unobservable individual and household characteristics that may also affect the migration decision. In our analysis, the use of different matching estimators, in the first place, and then the close results that we find implementing the OLS to estimate the household budget shares make us quite confident that migration is an exogenous process in this particular setting. Moreover, not taking the problem of selection into account can bias the results only if receiving remittances are perceived as transitory income or they cause a behavioural change with respect to family expenditure decision. Endogeneity of migration does not seem to be an issue when remittances are treated just as income and the household does not differentiate among the different sources of income. The advantage of using the OLS estimation technique is that it makes it simpler to compute the marginal budget shares and demand elasticities as presented above.

\footnotetext{
${ }^{9}$ For simplicity we use the same notation for the three different sources of remittances.

${ }^{10}$ Zeroes in the expenditure accounts for less than 2 per cent in the case of food and consumed-durables; around 17 per cent for health; 33 per cent for education; 69 per cent for house and land; 90 per cent for investment.

${ }^{11}$ The case of non-consumption represents a utility maximizing solution, as income constraint is possibly the reason explaining why the good is not affordable. The case of infrequency of consumption occurs when the period considered by the survey is not long enough; different types of expenditures have different periodicity.
} 


\section{Results}

\subsection{Estimates from PSM}

Household expenditures reflect family preferences for consumption and household characteristics are very important to understand how income is allocated among different types of goods. Table 4 contains the summary statistics of the variables - household composition variables and household head characteristics - used to investigate the average budget shares, which are then used to estimate the propensity scores. The propensity scores are computed respectively for receiving domestic remittances only, receiving international remittances only and receiving from both sources.

The estimation of the propensity scores reveals the effect of each covariate on the probability to receive remittances and given that the dependent variable is a binary outcome the logit model is used to compute the propensity scores. Table 5 shows the logistic regressions for the three mutually exclusive remittances status. Most of the explanatory variables have the expected sign. The probability of receiving remittances from any destination increases with the household size; the proportion of children in the household - both in the case of infant and toddlers ( 0 to 4 years) and children of school going age (5 to 15) - increases the probability of receiving domestic remittances but it is insignificant in the case of international transfers. Conversely, the proportion of elderly has the positive effects on the probability of receiving international transfers. Moreover, the proportion of women in the household increases significantly the probability of receiving remittances from any destination. Intuitively, those evidences show that transfers help to mitigate dependence in the case of vulnerable members (Clément, 2011). Households driven by women are more likely to be in one of the three remittances status and overall the probability of receiving one of the three treatments increases with the age of the household head. The secondary level of education of the household head has positive effect on the probability of receiving international remittances. Conversely, when the household head has tertiary education there is a negative effect on the probability of receiving domestic remittances and this negative impact is captured in the case of receiving transfers from multiple destinations. Holding agricultural land does not have any impact on the probability of receiving domestic or international transfers. However, it has some impact when both types of transfers are received. Overall, we find robust results across the different methods of matching for the various types of expenditures. However, the kernel estimator performs better in terms of bias ${ }^{12}$ reduction in each treatment setting: the Gaussian kernel estimator removes most of the bias between the treated and non-treated groups. For each exogenous variable, Table 6 reports the bias before and after the matching and the achieved percentage reduction in bias using

\footnotetext{
12 The bias is defined as the difference of the mean values of the treatment group and non-treatment group divided by
} the square root of the average sample variance in the treatment group and the not matched non treatment group. 
the kernel estimator. With few exceptions, the proportion of bias reduction for each variable after the matching ranges between 50 and 90 per cent. The only variable for which the differences between the two groups are not eliminated is household head having secondary education when the treatment is receiving both domestic and external remittances. However, the bias is quite small before matching and moreover this variable does not have any impact on the probability of receiving the treatment. Finally, the $t$-test shows that for each variable there is no significant difference in the mean after the matching.

The results of the average treatment effect on the treated (ATT) using the different matching estimators are reported in Table 7. Using the $t$-value to set the level of significance of receiving the treatment on the various expenditures, we find that when the treatment is identified in receiving domestic remittances there is no difference between treated and control groups in the allocation of the budget share and we conclude that domestic remittances do not change household behaviour. House and land is the only expenditure for which the matching estimators report a significant $t$ value. Household receiving domestic transfers invest less on house and land ${ }^{13}$, which is in line with Clément (2011) who finds that internal remittances decrease the proportion of expenditure devoted to housing and agriculture and concludes that internal remittances are used in non-productive expenditure in Tajikistan.

The results in Table 7 show that receiving international remittances versus no remittances impact negatively the proportion of expenditure on food and positively the household budget share on consumed and durable goods. ${ }^{14}$ More importantly, households receiving international transfers spend more on education and investment. The results are consistent across the different matching estimators. These results give some positive signs that remittances are used for investment purposes. Finally, we do not find significant differences in the expenditure behaviour when both domestic and international remittances are received, except for expenditure on health. Households receiving transfers from both internal and international destinations spend more on health compared to those who do not receive any transfers. Clément (2011) finds this positive relationship between expenditure on health and receiving remittances in the case of domestic transfers. He interprets expenditure on health as a short-term necessity and he does not conclude for a productive use of

\footnotetext{
13 This finding is not supported by the one nearest neighbour estimator which does not provide evidences of differences in behaviour between treated and control units with respect to expenditure on housing and land. However, the t-value reported by the one nearest neighbour is very close to the significant level and the relationship between receiving domestic transfers and expenditure on housing and land is negative. We conclude that the fact that t-statistic is slightly below the significant level may depend on a bad quality of matching, which is a problem that can occur when only one control unit is used for comparison.

${ }^{14}$ The effect is consistent with respect to the various matching methods except for the nearest neighbour for which the $t$ value is not significant. We suppose that it is not always possible to reach good matches when only one comparison unit is used in the matching.
} 
domestic transfers. In our case, we are not able to know which type of remittances - domestic or international - weighs more in the household consumption behaviour. We cannot conclude that more expenditure on health drives to a productive use of remittances because it could be a shortterm necessity.

\subsection{Ordinary Least Squares and the Working-Leser Model}

Using the OLS model to estimate the functional form expressed in equation (6), we compare the effect of remittances on different budget shares with the matching estimates. The mutually exclusive remittance statuses are expressed as dummy variables and their effect are jointly estimated with the household characteristics. We find that the sources of remittances have different effects on how expenditure is allocated among the type of commodities. Regarding internal sources, households receiving domestic remittances spend 1 per cent less on house and land. The other household expenditures are not affected by receiving domestic remittances. The matching estimators do not report any impact of domestic remittances on household expenditure behaviour except for house and land for which a negative impact is captured. Looking at the impact of international remittances on household budget shares we find that the expenditures affected are food, durable and consumed goods, education and investment. In particular, receiving external remittances decreases the expenditure on food by 4 per cent, increases the expenditure on durable and consumed goods by 2 per cent and the budget share allocated to education by 1 per cent. These results are in line with those found with the matching methods. Finally, receiving both domestic and external transfers increases expenditure on health while it does not affect any other type of expenditure. We conclude that overall the OLS estimates of the effect of remittances on household expenditure behaviour are consistent with the average treatment effect on the treated calculated with the matching methods and this evidence allows us to rely on them. Moreover, the OLS technique makes it possible to evaluate the impact of household characteristics on their expenditure behaviour.

We find that across the different types of household expenditures, gender and age of the household head are not relevant in the way the budget share is allocated; it is rather head's level of education that plays an important role in this decision. The composition of the household is important for understanding how the expenditure is allocated. The average budget share on food decreases as the size of the household increases, however the effect is quite small and as expected more important is the proportion of children in the household which shows a level of significance of 1 per cent. Infant/toddlers and children of school going age increase the expenditure on food by 13 and 15 per cent respectively. Households holding agricultural land spend 4 per cent more on food. 
We expected to find the contrary impact and it may depend on the low productivity of the soil due to rainfall shocks. Finally, better educated household heads decrease the share of expenditure on food by 10 (14) per cent when they have secondary (tertiary) education.

Looking at the budget share devoted to consumption and durable goods, we find that as the proportion of children increases, the expenditure on these goods decreases by 10 per cent when infant/toddlers are considered and by 9 per cent for children of school going age. Conversely, the proportion of elderly increases the expenditure on durables by 11 per cent. Households with agricultural land spend less on durables. Those households with a head holding secondary and tertiary education increase the expenditure on consumed and durable goods by 2 and 4 per cent respectively. We believe that better educated individuals not only are more likely to have a higher level of income compared to the less educated ones but they perhaps buy better quality and technological goods more, hence spend more on them. Expenditure on housing and land is negatively affected from all the variables regarding household compositions; only the level of education of the household head has positive impact on this type of expenditure. The secondary level of education of the household head increases the expenditure on housing by 9 per cent and by 1.6 per cent when the head has tertiary education.

The decision to devote a part of the total budget share to education is considered a way to invest in human capital and as expected, households with higher proportion of young family members of school going age - between 5 and 15 - increase the expenditure on education by 5 per cent. Conversely, expenditure on education decreases by 4 per cent with the proportion of infants and toddlers in the household. Also, as could be expected, the level of education of the household head is an important determinant of how much to spend on human capital: a head with secondary education increases the household expenditure on education by 2 per cent ( 3 per cent) when he (she) has tertiary education.

Expenditure on investment is not determined by the household composition. We find a positive effect of owning agricultural land on the decision to invest, as the category of investment includes expenditure on farming equipment and, as expected, those owning land are more likely to make this type of investment. The expenditure on investment goods decreases by 2 per cent if the head of the household is a woman. Expenditure on health is an indicator of the household wellbeing and it could also be important in raising labour productivity. Surprisingly, the share of expenditure on health does not depend on any of the household composition variables and a very small effect is given by the age of the household head. Households with older head spend slightly more on health, though a head with tertiary education decreases the household expenditure on health by almost 2 per cent. A possible explanation for it is that households with better educated 
individuals lead a healthy life-style: better quality of food etc. Also, we find that those households holding agricultural land spend 1 per cent more on health. We assume that for those households agriculture is the main activity and the healthy status of their members is fundamental for the productivity and therefore income of the household.

The last type of expenditure considered includes engagement, wedding and funeral. Larger households spend 0.2 per cent more on those events and also holding agricultural land has positive impact on those expenditures -- agriculture land is an indicator of living in rural areas where traditions are stronger.

Overall, the OLS estimates of the impact of the three different sources of remittances on the household expenditure behaviour are consistent with the average treatment effect of remittances on the different budget shares. This evidence allows us to extend the model including the log of total household expenditure. In Table 9 we report the OLS estimates of the Working-Leser model. The coefficients corresponding to the logarithm of total expenditure allow us to compute the marginal budget shares and expenditure elasticities of the commodities considered. On average, as total annual expenditure increases, households spend 10 per cent less on food while its impact on the budget share devoted to housing and land, health and other goods is positive and strongly significant. As the total annual expenditure increases, households spend 5 per cent more on housing and land, 1 per cent more on health and 2 per cent more on other types of goods. A small positive impact is captured for expenditure on investment, which rises by 0.6 per cent when total annual expenditure increases.

The introduction of the log of total annual expenditure as extra covariate in the estimation of the budget shares does not affect the impact of domestic remittances on the house and land expenditure, which remain negative. The positive effects of receiving international transfers on the household expenditure on durables goods, education and investment remain strong. However, international transfers do not affect the budget share on food when the total annual expenditure is introduced and we capture a negative impact of international remittances on house and land and other type of goods. Finally, household receiving remittances from diversified destinations spend more on health and again there is a negative impact of expenditure on housing, which was not captured in the previous estimations. When we consider the total annual expenditure, independently of the source of remittances, we find that transfers decrease the household share allocated to housing and land. The marginal budget shares and elasticities for each category of goods considered are computed using eqs. (10) and (11) and they are reported in Table 10. The figures reveal that for one Franc CFA increase in the household's budget, expenditure on food rises by 0.26 of a Franc, on consumed and durables by 0.30 of a Franc, on housing and land by 0.12 while on investment just 
0.02 of a Franc, on education and health, respectively, 0.05 and 0.08 of a Franc and finally on other expenditures by 0.14 of a Franc. Overall, at the margin, households devote more of their expenditure on consumed than investment goods. Then, the estimates for expenditure elasticities suggest that food is a necessity good and education is classified as normal good while the other commodities are luxury items. ${ }^{15}$ We find that the Senegalese households perceive education more important than other types of expenditures. We are not able to argue until which age (or school level) education is considered a normal good. It is possible that after a certain grade education is considered luxury expenditure though it is difficult to determine at which school level/grade that happens. But, in general the fact that education is a normal good means that households realize the value of human capital accumulation as an investment for a better life in the future.

Table 11 shows the estimated coefficients for the logarithm of household expenditure and its interaction with different sources of remittances. Our main interest is to determine whether the source of remittances affects the household marginal propensity to consume for each group of commodity considered. The interaction terms are insignificant in almost all budget shares considered, except that for food. The other controls are omitted from the table to conserve space and also because they are not the main interest in this analysis. In Table 12 we show the marginal budget shares and elasticities for each category of expenditure considered by remittances status. Overall, we do not observe a considerably different pattern of consumption among those households receiving and those not receiving transfers as well as the source of remittances does not seem to be relevant in explaining the household behaviour at the margin.

We conclude that when we consider the average impact of remittances on the household consumption behaviour we find that receiving remittances affect household expenditure decisions for some commodities and international remittances has the stronger effect. However, a further investigation reveals that recipient households do not show a different marginal behaviour compared to those who do not receive transfers. Moreover, the similar demand elasticities among the different types of recipient households suggest that how households consider goods - necessity, normal or luxury goods - is not affected by remittances.

\section{Conclusion}

Migrant's transfers can potentially play an important role in developing countries and it is important to understand how recipient households perceive and use them. The question on what remittances represent for the households is still a topic of debate. The way remittances are spent -

\footnotetext{
${ }^{15}$ The elasticity is greater than one and therefore the demand is relatively responsive to a change in price; the contrary happens for a necessity good for which the elasticity is less than one.
} 
on consumption or investment goods - is strictly determined by the context of the analysis. Some countries are able to promote a productive use of remittances better than others.

We contribute to the existing debate by investigating the impact of remittances on household expenditure behaviour in Senegal. The data used allowed us to identify four types of households: non-receiving; receiving remittances from internal migrants; recipients from international migrants; receiving from both domestic and international migrants. It is important to consider households according to their remittance status because migrants' transfers could differ not only in their amount but also with respect to their origin and where transfers are originated can affect how they are perceived by the receiving households.

The empirical analysis was conducted using propensity score matching techniques and the OLS to capture the marginal expenditure behaviour using the popular Working-Leser model. Among the different types of remittances, the matching estimators showed that international remittances have the stronger effect on the household expenditure behaviour: food, consumed and durables goods, education and investments are items in the budget share in which the average difference between treated and non-treated households is significant. Those receiving international transfers spend on average less on food and more on durables, education and investment. These results give some signal of a productive use of remittances. We also compare the propensity score matching estimates with the Working-Leser model framework which allows us to extend the analysis to the expenditure behaviour at the margin. We found similar results when we look at the average impact of remittances on the different categories of items. However, in terms of the impact of remittances on marginal spending behaviour we did not find a very significant role played by remittances and we concluded for a similar consumption patterns for household with different remittances status in Senegal. In the decision on how to allocate expenditure, remittances are treated just as any other source of income.

Our findings do not support the view of remittances as a valve for the development but it does not mean that migrants' transfers cannot be used in a productive way. Poverty and disparities in income per capita among developing countries help explain why households use remittances for different purposes. This last argument is supported by Adams et al. (2008a) who explain why they find different results in Ghana and Guatemala: low income-countries perhaps value income from remittances just as wage income but it could be possible that in the long run - after the household is able to provide a minimum level of satisfaction in the basic commodities - the role and perception of remittances change. This suggests that remittances can play a role in the development process only if there is a common effort to ensure some minimum standard of living among the whole population. We believe that better quality of information and an environment (or institutions and 
local governments) which stimulates investment can result in a better use of transfers. For example, improving quality of education and incentives to school attendance; promoting infrastructure, reducing uncertainty and creating conditions for making investments productive could all help foster a more productive use of remittances. 


\section{References}

Adams, R. Jr. (2011). Evaluating the Economic Impact of International Remittances on Developing Countries Using Household Surveys: A Literature Review. Journal of Development Studies 47(6), 809-828.

Adams, R. Jr., (2007). International Remittances and the Household : Analysis and Review of Global Evidence. Policy Research Working Paper Series 4116, The World Bank.

Adams, R. Jr., (1996). Remittances, Income Distribution, and Rural Asset Accumulation. International Food Policy Research Institute, Washington.

Adams, R. Jr., Cuecuecha, A. (2010a). Remittances, Household Expenditure and Investment in Guatemala. World Development 38(11), 1626-1641.

Adams, R. Jr., Cuecuecha, A. (2010b). The Economic Impact of International Remittances on Poverty and Household Consumption and Investment in Indonesia. Policy Research Working Paper Series 5433, The World Bank.

Adams, R. Jr., Cuecuecha, A., Page, J. (2008a). Remittances, Consumption and Investment in Ghana. Policy Research Working Paper Series 4515, The World Bank.

Adams, R. Jr., Cuecuecha, A., Page, J. (2008b). The Impact of Remittances on Poverty and Inequality in Ghana. Policy Research Working Paper Series 4732, The World Bank.

Ang, P.A., Sugiyarto, G., Jha, S. (2009). Remittances and Household Behaviour in the Philippines, ADB Economics Working Paper Series 188, Asian Development Bank.

ANSD (Agence Nationale de la Statistique et de la Démographie) du Sénégal (2004). Enquête Sénégalaise Auprès des Ménages (ESAM II). Rapport National. République du Sénégal, Ministère de l'Economie et des Finances

ANSD (Agence Nationale de la Statistique et de la Démographie) du Sénégal (2002). Troisième Recensement de la Population et de l'Habita (RGPH-III). Rapport National. République du Sénégal, Ministère de l'Economie et des Finances.

Becker, S.O., Ichino, A. (2002). Estimation of Average Treatment Effects Based on Propensity Scores, The Stata Journal 2(4), 358-377.

Caliendo, M., Kopeining S. (2008). Some Practical Guidance for the Implementation of Propensity Score Matching. Journal of Economic Surveys 22 (1).

Castaldo, A., Reilly, B. (2007). Do Migrant Remittances Affect the Consumption Patterns of Albanian Households. South-Eastern Europe Journal of Economics 5 (1), 25-54.

Catrinescu, N., Leon-Ledesma, M., Piracha, M., Quillin, B. (2009). Remittances, Institutions and Economic Growth. World Development 37 (1), 81-92.

Cattaneo, C. (2012). Migrants' International transfers and Educational Expenditure. Economics of Transition 20 (1),163-193. 
Chami, R., Fullenkamp, C., Jahjah, S. (2005). Are Immigrant Remittance Flows a Source of Capital for Development? IMF Staff Papers, Palgrave Macmillan, 52 (1), 55-81.

Cisse, F. (2011). Senegal. In Mohapatra, S., Ratha, D. (eds). Remittance Markets in Africa. Ch.8, 221-241, The World Bank.

Clément, M. (2011). Remittances and Expenditure Patterns in Tajikistan: A Propensity Score Matching Analysis. Asian Development Review 28 (2). 58-87.

Deaton, A. (1986). Demand Analysis. Handbook of Econometrics, New York: Elsevier Science Publisher.

Dehejia, R. H., Wahba, S. (2002). Propensity Score Matching for Nonexperimental Causal Studies. Review of Economics and Statistics, 84 (1), 151-161.

Di Bartolomeo, A., Thibaut, J., Perrin, D. (2010). Migration Profile: Senegal. CARIM - Robert Schuman Centre for Advanced Studies, July.

Edwards, A.C., Ureta, M. (2003). International Migration, Remittances, and Schooling: Evidence from El Salvador. Journal of Development Economics 72 (2), 429-62.

Esquivel, G., Guerta-Pineda, A. (2007). Remittances and Poverty in Mexico: A Propensity Score Matching Approach, Integration and Trade Journal 27 (July-December), 47-71.

Jettinger, B. (2005). Senegal Country Study: A Part of the Report on Informal Remittance Systems in Africa, Caribbean and Pacific (ACP) Countries (Ref: RO2CS008), ESRC Centre on Migration, Policy and Society (COMPAS).

Kifle, T. (2007). Do Remittances Encourage Investment in Education? Evidence from Eritrea. GEFAME Journal of African Studies, 4(1).

Narayan, P. K., Narayan, S., Mishra, S. (2011). Do Remittances Induce Inflation? Fresh Evidence from Developing Countries. Southern Economic Journal 77, 914-33.

Naudé, W. (2010). The Determinants of Migration from Sub-Saharan African Countries. Journal of African Economies 19 (3), 330-356.

Rosenbaum, P., Rubin, D. (1983). The Central Role of the Propensity Score in Observational Studies for Casual effects. Biometrika 70, 41-55.

Rosenbaum, P., Rubin, D. (1985). Constructing a Control Group using Multivariate Matched Sampling Methods that Incorporate the Propensity, American Statistician 39 (1), 33-38.

Sarr, A. (2007). An Overview of Senegal Rain Enhancement programme (SENREP): Bawaan. World Meteorological Organization. http://www.wmo.int/pages/prog/arep/wmp/documents/Sarr_Senegal.pdf

Seshan, G. (2012). Does Asymmetric Information in Transnational Households Affect Remittance Flows?

http://www.dartmouth.edu/ neudc2012/docs/paper_32.pdf 
Schueler, D. (2007). Incentive Effects of Transfers within the Extended Family: The Case of Indonesia. German Development Economic Conference, Gottingen 2007, N. 29.

Some, A.N. (2009). Migration au Sénégal: Profil National 2009. International Organization for Migration - IOM.

Tabuga, A.D. (2007). International Remittances and Household Expenditures: The Philippine Case. Philippines Institue for Development Studies, Discussion paper n. 2007-18.

Taylor, J. E., Mora, J. (2006). Does Migration Reshape Expenditures in Rural Households? Evidence from Mexico. Policy Research Working Paper Series 3842, The World Bank.

Yang, D. (2008). International Migration, Remittances, and Household Investment: Evidence from Philippine Migrants' Exchange Rate Shocks. The Economic Journal 118, 591-630.

Zarate-Hoyos, G.A. (2004). Consumption and Remittances in Migrant Households: Toward a Productive Use of Remittances. Contemporary Economic Policy 22 (4), 555-565. 
Table 1 - Some data description: households with and without migrants

$\begin{array}{lcccc}\begin{array}{l}\text { Household } \\ \text { characteristics }\end{array} & \begin{array}{c}\mathrm{HH} \text { with no } \\ \text { migrants }\end{array} & \begin{array}{c}\mathrm{HH} \text { with Internal } \\ \text { migrants }\end{array} & \begin{array}{c}\mathrm{HH} \text { with } \\ \text { International } \\ \text { migrants }\end{array} & \begin{array}{c}\mathrm{HH} \text { with both } \\ \text { Internal \& Int'l } \\ \text { migrant }\end{array}\end{array}$

$\begin{array}{lcccc}\begin{array}{l}\text { Age (head of the } \\ \text { household) }\end{array} & 51 & 53 & 53.7 & 59.7 \\ \begin{array}{l}\text { HH size } \\ \begin{array}{l}\text { Education } \\ \text { (members) }\end{array}\end{array} & 7.8 & 9 & 10 & 12.5 \\ \text { None } & 54.04 & 58.35 & 52.45 & 65.96 \\ \text { Primary } & 20.12 & 19.45 & 18.88 & 16.36 \\ \text { Secondary } & 17.86 & 17.60 & 22.31 & 14.94 \\ \text { Tertiary } & 7.91 & 4.61 & 6.36 & 2.74\end{array}$

${ }^{\text {** }}$ Percentage of members older than 17 with the corresponding level of education

Table 2 - Description of the expenditure categories

Category Description

Average

budget

share

Food cereals, legumes, oilseeds, tubers, vegetables, fruit, meat

etc.

Consumed and clothing, footwear, cost of mobile phone, internet, luxury

durables

(CD goods)

goods, utilities, appliances, vehicles, computer, electronic goods.

House and

Land

house, land, home improvement, rent, mortgage, loan

0.0676

repayment

Investment

productive assets, setting a business, open a store, farming

0.0157 equipment.

Education

books, school supplies, uniforms, registration fees.

0.050

Health

doctor fees, lab fees, hospitalization, prescription.

0.07704

Other goods

include expenditure on wedding, engagement, funerals. 
Table 3 - Average budget shares for each commodity by remittances status

Food Consumed\& House\&Land Investment Education Health Other

Durables

(CD)

\begin{tabular}{|c|c|c|c|c|c|c|c|}
\hline Internal remittances & 0.408 & 0.281 & 0.0439 & 0.014 & 0.051 & 0.801 & 0.12 \\
\hline No remittances & 0.3669 & 0.2965 & 0.799 & 0.013 & 0.045 & 0.072 & 0.124 \\
\hline$P$-value & 0.0010 & 0.193 & 0.0002 & 0.798 & 0.1510 & 0.193 & 0.613 \\
\hline $\begin{array}{l}\text { International } \\
\text { remittances }\end{array}$ & 0.325 & 0.329 & 0.068 & 0.0196 & 0.063 & 0.075 & 0.117 \\
\hline No remittances & 0.3669 & 0.2965 & 0.799 & 0.013 & 0.045 & 0.072 & 0.124 \\
\hline$P$-value & 0.0001 & 0.001 & 0.2121 & 0.1515 & 0.000 & 0.559 & 0.364 \\
\hline $\begin{array}{l}\text { Internal\&International } \\
\text { remittances }\end{array}$ & 0.37 & 0.289 & 0.434 & 0.18 & 0.043 & 0.102 & 0.13 \\
\hline No remittances & 0.3669 & 0.2965 & 0.799 & 0.013 & 0.045 & 0.072 & 0.124 \\
\hline$P$-value & 0.712 & 0.642 & 0.0040 & 0.423 & 0.807 & 0.0004 & 0.657 \\
\hline
\end{tabular}

\footnotetext{
Note: (1) Number of observations with positive expenditure values (>0) are: for Food 1903; for CD (Consumed and durable) goods

1913; for House and Land 589; for Investment 185; for Education 1290; for Health 1603; for Other 1504.

(2) P-values show the level of significance at which we can reject the hypothesis of equal means between the sample proportion of

remittance-receiver and non-receiver households
} 
Table 4: Summary statistics of the variables used in the estimations

Variables Mean

\begin{tabular}{ll}
\hline Log of total Household Expenditure & $14.70(0.896)$ \\
Household size & $9.17(5.67)$ \\
Proportion of children (0-4) & $0.12(0.12)$ \\
Proportion of children (5-15) & $0.24(0.17)$ \\
Proportion of elderly (>62) & $0.06(0.10)$ \\
Proportion of women (>15) & $0.34(0.17)$ \\
Having agriculture land (yes=1) & 0.41 \\
Household Head gender (Female=1) & 29.86 \\
Age of the Household Head & $52.97(14.86)$ \\
HH head has secondary education (yes=1) & 0.149 \\
HH head has tertiary education (yes=1) & 0.077 \\
HH receiving no remittances (yes=1) & 0.488 \\
HH receiving Internal remittances (yes=1) & 0.168 \\
HH receiving International remittances (yes=1) & 0.248 \\
HH receiving Internal and International remittances & 0.093 \\
(yes=1) & \\
\hline
\end{tabular}

Notes: (1) No. of Observations:1939;

(2) Standard deviation in parentheses (for continuous variables only). 
Table 5: Logit regression for the remittance receipts.

\begin{tabular}{|c|c|c|c|}
\hline VARIABLES & $\begin{array}{l}\text { Internal } \\
\text { remittances }\end{array}$ & $\begin{array}{l}\text { International } \\
\text { remittances }\end{array}$ & $\begin{array}{c}\text { Internal \& Int'I } \\
\text { remittances }\end{array}$ \\
\hline \multirow[t]{2}{*}{ Household size } & $0.0194^{\star \star}$ & $0.0492^{\star \star \star}$ & $0.0695^{\star \star \star}$ \\
\hline & $(0.00944)$ & $(0.00793)$ & $(0.0102)$ \\
\hline \multirow[t]{2}{*}{ Prop of children $(0-4)$} & $1.235^{\star \star \star}$ & 0.442 & $1.247^{* *}$ \\
\hline & $(0.356)$ & $(0.324)$ & $(0.490)$ \\
\hline \multirow[t]{2}{*}{ Prop of children $(5-15)$} & $1.058^{\star \star \star}$ & 0.362 & $1.079^{\star * *}$ \\
\hline & $(0.289)$ & $(0.253)$ & $(0.397)$ \\
\hline \multirow[t]{2}{*}{ Prop of elderly (>62) } & 0.560 & $0.942^{* *}$ & $1.294^{* * *}$ \\
\hline & $(0.425)$ & $(0.381)$ & $(0.470)$ \\
\hline \multirow[t]{2}{*}{ Prop of women $(>15)$} & $0.774^{\star *}$ & $0.707^{* * *}$ & $1.738^{* * *}$ \\
\hline & $(0.308)$ & $(0.259)$ & $(0.408)$ \\
\hline \multirow[t]{2}{*}{ Owning agriculture land } & 0.121 & 0.108 & $0.208^{*}$ \\
\hline & $(0.0872)$ & $(0.0808)$ & $(0.110)$ \\
\hline \multirow[t]{2}{*}{$\mathrm{HH}$ head ( =female) } & $2.127^{\star \star \star}$ & $1.921^{\star \star \star}$ & $2.326^{\star \star \star}$ \\
\hline & $(0.341)$ & $(0.299)$ & $(0.458)$ \\
\hline \multirow[t]{2}{*}{ Age of the $\mathrm{HH}$ head } & $0.0411^{* * *}$ & $0.0221^{* * *}$ & $0.0524^{* * *}$ \\
\hline & $(0.00881)$ & $(0.00781)$ & $(0.0110)$ \\
\hline \multirow[t]{2}{*}{$\mathrm{HH}$ head*age } & $-0.0297^{\star * *}$ & $-0.0204^{* * *}$ & $-0.0328^{* * *}$ \\
\hline & $(0.00628)$ & $(0.00545)$ & $(0.00808)$ \\
\hline \multirow[t]{2}{*}{$\mathrm{HH}$ head with secondary educ } & -0.0198 & $0.280^{* * *}$ & 0.227 \\
\hline & $(0.124)$ & $(0.104)$ & $(0.148)$ \\
\hline \multirow[t]{2}{*}{$\mathrm{HH}$ head with tertiary educ } & $-0.328^{*}$ & 0.135 & $-0.431^{*}$ \\
\hline & $(0.178)$ & $(0.134)$ & $(0.259)$ \\
\hline \multirow[t]{2}{*}{ Constant } & $-4.463^{* * *}$ & $-3.682^{* * *}$ & $-6.480^{* * *}$ \\
\hline & $(0.508)$ & $(0.432)$ & $(0.695)$ \\
\hline Observations & 1,275 & 1,430 & 1,130 \\
\hline
\end{tabular}

Notes: (1) "No remittances" is the base category in each Logit regression;

(2) Standard errors in parentheses; ${ }^{* * \star} p<0.01,{ }^{* *} p<0.05,{ }^{*} p<0.1$ 
Table 6: Balancing tests for the propensity score matching - Gaussian Kernel estimator

\begin{tabular}{|c|c|c|c|c|}
\hline & Sample & \%bias & $\begin{array}{c}\text { \%reduction in } \\
\text { bias }\end{array}$ & t- test \\
\hline \multicolumn{5}{|l|}{ Internal Remittances } \\
\hline \multirow{2}{*}{ Household size } & Unmatched & 22.8 & & $3.53^{\star * *}$ \\
\hline & Matched & -0.8 & 96.3 & -0.10 \\
\hline \multirow[t]{2}{*}{ Prop of children $(0-4)$} & Unmatched & 20.3 & & $3.18^{\star \star \star}$ \\
\hline & Matched & -0.1 & 99.7 & -0.01 \\
\hline \multirow[t]{2}{*}{ Prop of children $(5-15)$} & Unmatched & 28.1 & & $4.31^{* * *}$ \\
\hline & Matched & 2.0 & 92.9 & 0.26 \\
\hline \multirow[t]{2}{*}{ Prop of elderly (> 62) } & Unmatched & 4.0 & & 0.58 \\
\hline & Matched & 1.7 & 57.8 & 0.21 \\
\hline \multirow[t]{2}{*}{ Prop of women (> 62) } & Unmatched & 15.8 & & $2.35^{\star *}$ \\
\hline & Matched & 2.7 & 82.9 & 0.35 \\
\hline \multirow[t]{2}{*}{ Owning agriculture land } & Unmatched & 11.8 & & $1.84^{*}$ \\
\hline & Matched & -3.4 & 71.0 & -0.43 \\
\hline \multirow[t]{2}{*}{$\mathrm{HH}$ head ( =female) } & Unmatched & 45.4 & & $7.51^{\star * *}$ \\
\hline & Matched & 4.3 & 90.6 & 0.49 \\
\hline \multirow[t]{2}{*}{ Age of the $\mathrm{HH}$ head } & Unmatched & 5.6 & & 0.88 \\
\hline & Matched & 3.0 & 45.5 & 0.38 \\
\hline \multirow[t]{2}{*}{ HH head*age } & Unmatched & 32.6 & & $5.12^{\star \star *}$ \\
\hline & Matched & 6.4 & 80.4 & 0.81 \\
\hline \multirow[t]{2}{*}{$\mathrm{HH}$ head with secondary educ } & Unmatched & -9.0 & & -1.37 \\
\hline & Matched & 2.0 & 78.0 & 0.27 \\
\hline \multirow[t]{2}{*}{$\mathrm{HH}$ head with tertiary educ } & Unmatched & -27.9 & & $-3.91^{\star \star *}$ \\
\hline & Matched & -4.6 & 83.4 & -0.75 \\
\hline \multicolumn{5}{|l|}{ International Remittances } \\
\hline \multirow[t]{2}{*}{ Household size } & Unmatched & 30.0 & & $5.56^{\star \star *}$ \\
\hline & Matched & 4.3 & 85.8 & 0.63 \\
\hline \multirow[t]{2}{*}{ Prop of children $(0-4)$} & Unmatched & 7.9 & & 1.40 \\
\hline & Matched & 4.6 & 42.2 & 0.72 \\
\hline \multirow[t]{2}{*}{ Prop of children $(5-15)$} & Unmatched & 12.1 & & $2.15^{\star}$ \\
\hline & Matched & 5.6 & 54.2 & 0.86 \\
\hline Prop of elderly (>62) & Unmatched & 6.9 & & 1.19 \\
\hline & Matched & -6.2 & 10.7 & -0.80 \\
\hline Prop of women (>15) & Unmatched & 34.9 & & $6.13^{\star * \star}$ \\
\hline & Matched & -3.4 & 90.3 & -0.48 \\
\hline Owning agriculture land & Unmatched & -2.2 & & -0.39 \\
\hline & Matched & -1.8 & 18.1 & -0.28 \\
\hline HH head ( =female) & Unmatched & 63.3 & & $11.83^{* \star *}$ \\
\hline & Matched & 0.9 & 98.5 & 0.13 \\
\hline Age of the $\mathrm{HH}$ head & Unmatched & 3.9 & & 0.71 \\
\hline & Matched & 2.0 & 49.9 & 0.30 \\
\hline $\mathrm{HH}$ head $^{*}$ age & Unmatched & 46.1 & & $8.43^{\star * \star}$ \\
\hline & Matched & 1.6 & 96.4 & 0.24 \\
\hline $\mathrm{HH}$ head with secondary educ & Unmatched & 8.6 & & 1.56 \\
\hline & Matched & -1.6 & 82.0 & -0.23 \\
\hline $\mathrm{HH}$ head with tertiary educ & Unmatched & -9.3 & & -1.63 \\
\hline & Matched & -0.5 & 94.6 & -0.08 \\
\hline $\begin{array}{l}\text { Internal \& International } \\
\text { Remittances }\end{array}$ & & & & \\
\hline Household size & Unmatched & 63.0 & & $9.35^{\star \star \star}$ \\
\hline & Matched & -1.3 & 97.9 & -0.12 \\
\hline Prop of children $(0-4)$ & Unmatched & 14.9 & & $1.78^{*}$ \\
\hline & Matched & 4.7 & 68.3 & 0.47 \\
\hline Prop of children $(5-15)$ & Unmatched & 16.5 & & $2.00^{*}$ \\
\hline & Matched & 7.5 & 54.7 & 0.73 \\
\hline Prop of elderly (>62) & Unmatched & 27.5 & & $3.25^{\star * \star}$ \\
\hline & Matched & -6.0 & 78.3 & -0.46 \\
\hline Prop of women & Unmatched & 36.2 & & $4.31^{* * *}$ \\
\hline & Matched & 0.4 & 98.8 & 0.04 \\
\hline Owning agriculture land & Unmatched & 23.5 & & $2.93^{\star *}$ \\
\hline & Matched & 4.7 & 79.9 & 0.44 \\
\hline HH head (=female) & Unmatched & 35.9 & & $4.78^{\star \star *}$ \\
\hline & Matched & 5.5 & 84.7 & 0.47 \\
\hline
\end{tabular}




\begin{tabular}{|c|c|c|c|c|}
\hline & Sample & \%bias & $\begin{array}{c}\text { \%reduction in } \\
\text { bias }\end{array}$ & t- test \\
\hline Age of the $\mathrm{HH}$ head & $\begin{array}{l}\text { Unmatched } \\
\text { Matched }\end{array}$ & $\begin{array}{l}48.4 \\
-3.6\end{array}$ & 92.6 & $\begin{array}{l}6.14^{\star * \star} \\
-0.33\end{array}$ \\
\hline \multirow[t]{2}{*}{ HH head*age } & Unmatched & 54.1 & & $6.65^{\star * *}$ \\
\hline & Matched & 1.5 & 97.2 & 0.14 \\
\hline \multirow[t]{2}{*}{ HH head with secondary educ } & Unmatched & 0.5 & & 0.06 \\
\hline & Matched & -2.9 & -486.1 & -0.26 \\
\hline \multirow[t]{2}{*}{$\mathrm{HH}$ head with tertiary educ } & Unmatched & -34.0 & & $-3.53^{\star \star *}$ \\
\hline & Matched & -3.3 & 90.3 & -0.46 \\
\hline
\end{tabular}


Table 7: Propensity score estimates

\begin{tabular}{|c|c|c|c|c|c|c|c|c|c|c|}
\hline & \multicolumn{2}{|c|}{ Nearest neighbour } & \multicolumn{2}{|c|}{$\begin{array}{c}\text { Five Nearest } \\
\text { neighbour }\end{array}$} & \multicolumn{2}{|c|}{$\begin{array}{c}\text { Ten Nearest } \\
\text { neighbour }\end{array}$} & \multicolumn{2}{|c|}{ Kernel } & \multicolumn{2}{|c|}{$\begin{array}{c}\text { Radius calibre } \\
(0.05)\end{array}$} \\
\hline & ATT & $\mathrm{t}$ & ATT & $\mathrm{t}$ & ATT & $\mathrm{t}$ & ATT & $\mathrm{t}$ & ATT & $\mathrm{t}$ \\
\hline \multicolumn{11}{|c|}{ INTERNAL REMITTANCES } \\
\hline Food & $\begin{array}{c}0.017 \\
(0.015)\end{array}$ & 1.15 & $\begin{array}{c}0.010 \\
(0.014)\end{array}$ & 0.72 & $\begin{array}{c}0.015 \\
(0.014)\end{array}$ & 1.06 & $\begin{array}{c}0.015 \\
(0.013)\end{array}$ & 1.15 & $\begin{array}{c}0.016 \\
(0.013)\end{array}$ & 1.18 \\
\hline CD goods & $\begin{array}{l}-0.006 \\
(0.013)\end{array}$ & -0.49 & $\begin{array}{c}0.002 \\
(0.013)\end{array}$ & 0.21 & $\begin{array}{c}0.002 \\
(0.013)\end{array}$ & 0.21 & $\begin{array}{c}0.003 \\
(0.012)\end{array}$ & 0.29 & $\begin{array}{c}0.003 \\
(0.012)\end{array}$ & 0.29 \\
\hline House\&land & $\begin{array}{l}-0.016 \\
(0.010)\end{array}$ & -1.56 & $\begin{array}{l}-0.018 \\
(0.010)\end{array}$ & $-1.83^{\star}$ & $\begin{array}{l}-0.018 \\
(0.009)\end{array}$ & $-1.85^{\star}$ & $\begin{array}{l}-0.020 \\
(0.009)\end{array}$ & $-2.11^{\star *}$ & $\begin{array}{l}-0.021 \\
(0.009)\end{array}$ & $-2.15^{\star \star}$ \\
\hline Investment & $\begin{array}{c}0.001 \\
(0.005)\end{array}$ & 0.39 & $\begin{array}{c}0.004 \\
(0.004)\end{array}$ & 0.85 & $\begin{array}{c}0.002 \\
(0.005)\end{array}$ & 0.52 & $\begin{array}{c}0.001 \\
(0.004)\end{array}$ & 0.36 & $\begin{array}{c}0.001 \\
(0.004)\end{array}$ & 0.35 \\
\hline Education & $\begin{array}{c}0.004 \\
(0.005)\end{array}$ & 0.92 & $\begin{array}{l}0.005 \\
(0.005)\end{array}$ & 1.08 & $\begin{array}{c}0.004 \\
(0.004)\end{array}$ & 0.85 & $\begin{array}{l}0.006 \\
(0.004)\end{array}$ & 1.33 & $\begin{array}{c}0.006 \\
(0.004)\end{array}$ & 1.30 \\
\hline Health & $\begin{array}{c}0.003 \\
(0.007)\end{array}$ & 0.47 & $\begin{array}{c}0.006 \\
(0.007)\end{array}$ & 0.82 & $\begin{array}{c}0.007 \\
(0.007)\end{array}$ & 0.97 & $\begin{array}{c}0.007 \\
(0.006)\end{array}$ & 1.08 & $\begin{array}{c}0.007 \\
(0.006)\end{array}$ & 1.05 \\
\hline Other & $\begin{array}{l}-0.005 \\
(0.010) \\
\end{array}$ & -0.51 & $\begin{array}{c}-0.009 \\
(0.010) \\
\end{array}$ & -0.93 & $\begin{array}{c}-0.012 \\
(0.009) \\
\end{array}$ & -1.30 & $\begin{array}{c}-0.013 \\
(0.009) \\
\end{array}$ & -1.41 & $\begin{array}{c}-0.013 \\
(0.009) \\
\end{array}$ & -1.37 \\
\hline \multicolumn{11}{|c|}{ INTERNATIONAL REMITTANCES } \\
\hline Food & $\begin{array}{l}-0.040 \\
(0.011)\end{array}$ & $-3.38^{\star \star \star}$ & $\begin{array}{l}-0.037 \\
(0.012)\end{array}$ & $-2.90^{\star \star \star}$ & $\begin{array}{l}-0.038 \\
(0.012)\end{array}$ & $-3.10^{\star \star \star}$ & $\begin{array}{l}-0.038 \\
(0.012)\end{array}$ & $-3.13^{\star \star \star}$ & $\begin{array}{l}-0.038 \\
(0.012)\end{array}$ & $-3.16^{\star \star \star}$ \\
\hline CD goods & $\begin{array}{c}0.019 \\
(0.011)\end{array}$ & 1.63 & $\begin{array}{c}0.020 \\
(0.012)\end{array}$ & $1.68^{*}$ & $\begin{array}{c}0.025 \\
(0.012)\end{array}$ & $2.08^{\star \star}$ & $\begin{array}{c}0.024 \\
(0.011)\end{array}$ & $2.08^{\star \star}$ & $\begin{array}{c}0.024 \\
(0.011)\end{array}$ & $2.07^{\star \star}$ \\
\hline House\&land & $\begin{array}{c}0.003 \\
(0.010)\end{array}$ & 0.30 & $\begin{array}{l}-0.007 \\
(0.010)\end{array}$ & -0.70 & $\begin{array}{l}-0.006 \\
(0.010)\end{array}$ & -0.64 & $\begin{array}{c}-0.003 \\
(0.010)\end{array}$ & -0.33 & $\begin{array}{l}-0.003 \\
(0.010)\end{array}$ & -0.30 \\
\hline Investment & $\begin{array}{c}0.006 \\
(0.005)\end{array}$ & 1.35 & $\begin{array}{c}0.009 \\
(0.005)\end{array}$ & $1.88^{\star}$ & $\begin{array}{c}0.009 \\
(0.005)\end{array}$ & $1.84^{\star}$ & $\begin{array}{c}0.009 \\
(0.005)\end{array}$ & $1.81^{*}$ & $\begin{array}{c}0.009 \\
(0.005)\end{array}$ & $1.80^{\star}$ \\
\hline Education & $\begin{array}{c}0.016 \\
(0.005)\end{array}$ & $3.08^{\star \star \star}$ & $\begin{array}{c}0.015 \\
(0.005)\end{array}$ & $2.91^{\star \star \star}$ & $\begin{array}{c}0.016 \\
(0.005)\end{array}$ & $3.22^{\star \star \star}$ & $\begin{array}{c}0.016 \\
(0.005)\end{array}$ & $3.26^{\star \star \star}$ & $\begin{array}{c}0.016 \\
(0.005)\end{array}$ & $3.27^{\star \star \star}$ \\
\hline Health & $\begin{array}{l}-0.001 \\
(0.005)\end{array}$ & -0.23 & $\begin{array}{l}0.0007 \\
(0.006)\end{array}$ & 0.11 & $\begin{array}{l}0.0009 \\
(0.006)\end{array}$ & 0.16 & $\begin{array}{l}-0.001 \\
(0.006)\end{array}$ & -0.24 & $\begin{array}{l}-0.001 \\
(0.006)\end{array}$ & -0.21 \\
\hline Other & $\begin{array}{l}-0.003 \\
(0.008) \\
\end{array}$ & -0.44 & $\begin{array}{l}-0.001 \\
(0.009) \\
\end{array}$ & -0.21 & $\begin{array}{r}-0.006 \\
(0.009) \\
\end{array}$ & -0.71 & $\begin{array}{l}-0.006 \\
(0.009) \\
\end{array}$ & -0.76 & $\begin{array}{c}-0.007 \\
(0.009) \\
\end{array}$ & -0.79 \\
\hline \multicolumn{11}{|c|}{ INTERNAL \& INTERNATIONAL REMITTANCES } \\
\hline Food & $\begin{array}{c}0.003 \\
(0.020)\end{array}$ & 0.16 & $\begin{array}{c}0.003 \\
(0.018)\end{array}$ & 0.16 & $\begin{array}{c}0.004 \\
(0.018)\end{array}$ & 0.24 & $\begin{array}{l}-0.004 \\
(0.017)\end{array}$ & -0.27 & $\begin{array}{l}-0.005 \\
(0.017)\end{array}$ & -0.31 \\
\hline CD goods & $\begin{array}{c}0.008 \\
(0.019)\end{array}$ & 0.46 & $\begin{array}{l}-0.006 \\
(0.017)\end{array}$ & -0.34 & $\begin{array}{c}-0.003 \\
(0.017)\end{array}$ & -0.19 & $\begin{array}{c}0.001 \\
(0.016)\end{array}$ & 0.07 & $\begin{array}{c}0.002 \\
(0.016)\end{array}$ & 0.14 \\
\hline House\&land & $\begin{array}{l}-0.011 \\
(0.013)\end{array}$ & -0.89 & $\begin{array}{l}-0.017 \\
(0.012)\end{array}$ & -1.40 & $\begin{array}{l}-0.016 \\
(0.011)\end{array}$ & -1.40 & $\begin{array}{l}-0.016 \\
(0.012)\end{array}$ & -1.30 & $\begin{array}{l}-0.016 \\
(0.012)\end{array}$ & -1.33 \\
\hline Investment & $\begin{array}{c}0.004 \\
(0.007)\end{array}$ & 0.61 & $\begin{array}{c}0.006 \\
(0.007)\end{array}$ & 0.84 & $\begin{array}{c}0.006 \\
(0.007)\end{array}$ & 0.82 & $\begin{array}{c}0.005 \\
(0.007)\end{array}$ & 0.72 & $\begin{array}{c}0.005 \\
(0.007)\end{array}$ & 0.76 \\
\hline Education & $\begin{array}{l}-0.001 \\
(0.007)\end{array}$ & -0.24 & $\begin{array}{l}-0.003 \\
(0.006)\end{array}$ & -0.48 & $\begin{array}{l}-0.005 \\
(0.006)\end{array}$ & -0.79 & $\begin{array}{c}-0.002 \\
(0.006)\end{array}$ & -0.40 & $\begin{array}{c}-0.002 \\
(0.006)\end{array}$ & -0.38 \\
\hline Health & $\begin{array}{c}0.021 \\
(0.012)\end{array}$ & $1.76^{\star}$ & $\begin{array}{c}0.025 \\
(0.011)\end{array}$ & $2.23^{\star *}$ & $\begin{array}{c}0.020 \\
(0.011)\end{array}$ & $1.87^{*}$ & $\begin{array}{c}0.021 \\
(0.011)\end{array}$ & $1.95^{\star}$ & $\begin{array}{c}0.021 \\
(0.011)\end{array}$ & $1.95^{\star}$ \\
\hline Other & $\begin{array}{r}-0.025 \\
(0.015) \\
\end{array}$ & -1.64 & $\begin{array}{l}-0.008 \\
(0.014) \\
\end{array}$ & -0.62 & $\begin{array}{r}-0.006 \\
(0.013) \\
\end{array}$ & -0.47 & $\begin{array}{r}-0.005 \\
(0.013) \\
\end{array}$ & -0.39 & $\begin{array}{l}-0.005 \\
(0.013) \\
\end{array}$ & -0.41 \\
\hline
\end{tabular}

Notes: (1) CD Goods is "consumed and durable" goods; Other includes expenditure on wedding, engagement, funerals.

(2) Robust standard errors in parentheses, ${ }^{* *} p<0.01,{ }^{* *} p<0.05,{ }^{*} p<0.1$ 
Table 8: OLS Estimates of Budget Share Equations

\begin{tabular}{|c|c|c|c|c|c|c|c|}
\hline VARIABLES & $\begin{array}{c}(1) \\
\text { Food } \\
\end{array}$ & $\begin{array}{c}(2) \\
\text { CD goods } \\
\end{array}$ & $\begin{array}{c}(3) \\
\text { House\&land } \\
\end{array}$ & $\begin{array}{c}(4) \\
\text { Investment }\end{array}$ & $\begin{array}{c}(5) \\
\text { Education } \\
\end{array}$ & $\begin{array}{c}(6) \\
\text { Health } \\
\end{array}$ & $\begin{array}{c}(7) \\
\text { Other } \\
\end{array}$ \\
\hline Household size & $\begin{array}{l}-0.00149^{*} \\
(0.000878)\end{array}$ & $\begin{array}{c}0.000999 \\
(0.000789)\end{array}$ & $\begin{array}{c}-0.00230^{\star * \star} \\
(0.000692)\end{array}$ & $\begin{array}{l}-0.000215 \\
(0.000338)\end{array}$ & $\begin{array}{c}0.000370 \\
(0.000319)\end{array}$ & $\begin{array}{l}-0.000303 \\
(0.000419)\end{array}$ & $\begin{array}{l}0.00297^{\star \star *} \\
(0.000864)\end{array}$ \\
\hline Prop of children $(0-4)$ & $\begin{array}{l}0.137^{\star * *} \\
(0.0357)\end{array}$ & $\begin{array}{l}-0.101^{* * *} \\
(0.0332)\end{array}$ & $\begin{array}{l}-0.0586^{\star} \\
(0.0320)\end{array}$ & $\begin{array}{c}-0.00696 \\
(0.0143)\end{array}$ & $\begin{array}{c}-0.0399 * * * \\
(0.0128)\end{array}$ & $\begin{array}{c}0.0295 \\
(0.0190)\end{array}$ & $\begin{array}{c}0.0438 \\
(0.0273)\end{array}$ \\
\hline Prop of children $(5-15)$ & $\begin{array}{l}0.156^{\star * *} \\
(0.0285)\end{array}$ & $\begin{array}{c}-0.0959^{* * *} \\
(0.0272)\end{array}$ & $\begin{array}{c}-0.0903^{* * *} \\
(0.0262)\end{array}$ & $\begin{array}{l}0.00762 \\
(0.0116)\end{array}$ & $\begin{array}{c}0.0583^{* * *} \\
(0.0116)\end{array}$ & $\begin{array}{r}-0.00552 \\
(0.0144)\end{array}$ & $\begin{array}{l}-0.0275 \\
(0.0214)\end{array}$ \\
\hline Prop of elderly (>62) & $\begin{array}{c}0.0281 \\
(0.0521)\end{array}$ & $\begin{array}{c}0.113^{* *} \\
(0.0548)\end{array}$ & $\begin{array}{l}-0.140^{* * *} \\
(0.0288)\end{array}$ & $\begin{array}{r}-0.00792 \\
(0.0128)\end{array}$ & $\begin{array}{c}-0.0469^{* \star *} \\
(0.0144)\end{array}$ & $\begin{array}{c}0.0472 \\
(0.0325)\end{array}$ & $\begin{array}{l}0.00974 \\
(0.0323)\end{array}$ \\
\hline Prop of women (>15) & $\begin{array}{c}0.0414 \\
(0.0289)\end{array}$ & $\begin{array}{c}0.0293 \\
(0.0311)\end{array}$ & $\begin{array}{c}-0.0853^{* \star *} \\
(0.0294)\end{array}$ & $\begin{array}{c}-0.00665 \\
(0.0115)\end{array}$ & $\begin{array}{c}-0.00486 \\
(0.0118)\end{array}$ & $\begin{array}{c}0.0176 \\
(0.0162)\end{array}$ & $\begin{array}{c}0.0139 \\
(0.0247)\end{array}$ \\
\hline Owning agriculture land & $\begin{array}{l}0.0487^{* \star *} \\
(0.00911)\end{array}$ & $\begin{array}{l}-0.0915^{* * *} \\
(0.00846)\end{array}$ & $\begin{array}{l}-0.0205^{\star * *} \\
(0.00665)\end{array}$ & $\begin{array}{l}0.0143^{* * *} \\
(0.00350)\end{array}$ & $\begin{array}{l}-0.00392 \\
(0.00358)\end{array}$ & $\begin{array}{l}0.0147^{\star \star *} \\
(0.00510)\end{array}$ & $\begin{array}{l}0.0384^{* * *} \\
(0.00709)\end{array}$ \\
\hline $\mathrm{HH}$ head ( =female) & $\begin{array}{c}0.0187 \\
(0.0340)\end{array}$ & $\begin{array}{l}-0.0226 \\
(0.0319)\end{array}$ & $\begin{array}{c}0.0130 \\
(0.0263)\end{array}$ & $\begin{array}{c}-0.0254^{* *} \\
(0.0114)\end{array}$ & $\begin{array}{l}0.00795 \\
(0.0141)\end{array}$ & $\begin{array}{c}0.0180 \\
(0.0205)\end{array}$ & $\begin{array}{l}-0.0120 \\
(0.0265)\end{array}$ \\
\hline Age of the $\mathrm{HH}$ head & $\begin{array}{c}0.000960 \\
(0.000878)\end{array}$ & $\begin{array}{l}-0.000632 \\
(0.000822)\end{array}$ & $\begin{array}{l}-0.000463 \\
(0.000646)\end{array}$ & $\begin{array}{l}-0.000416 \\
(0.000364)\end{array}$ & $\begin{array}{c}0.000496 \\
(0.000339)\end{array}$ & $\begin{array}{l}0.000854^{*} \\
(0.000512)\end{array}$ & $\begin{array}{l}-0.000865 \\
(0.000675)\end{array}$ \\
\hline HH headªge & $\begin{array}{l}-0.000737 \\
(0.000605)\end{array}$ & $\begin{array}{l}0.001000^{*} \\
(0.000587)\end{array}$ & $\begin{array}{l}-0.000178 \\
(0.000447)\end{array}$ & $\begin{array}{c}0.000252 \\
(0.000192)\end{array}$ & $\begin{array}{l}-0.000152 \\
(0.000255)\end{array}$ & $\begin{array}{l}-0.000523 \\
(0.000367)\end{array}$ & $\begin{array}{r}0.000378 \\
(0.000465)\end{array}$ \\
\hline $\mathrm{HH}$ head with secondary educ & $\begin{array}{c}-0.102^{* * *} \\
(0.0101)\end{array}$ & $\begin{array}{c}0.0190^{*} \\
(0.0111)\end{array}$ & $\begin{array}{c}0.0409^{\star * *} \\
(0.0120)\end{array}$ & $\begin{array}{r}-0.000192 \\
(0.00471)\end{array}$ & $\begin{array}{l}0.0261^{\star * *} \\
(0.00567)\end{array}$ & $\begin{array}{c}0.00884 \\
(0.00741)\end{array}$ & $\begin{array}{c}0.00586 \\
(0.00867)\end{array}$ \\
\hline $\mathrm{HH}$ head with tertiary educ & $\begin{array}{l}-0.144^{* * *} \\
(0.0136)\end{array}$ & $\begin{array}{c}0.0441^{* * *} \\
(0.0160)\end{array}$ & $\begin{array}{c}0.0903^{* * *} \\
(0.0193)\end{array}$ & $\begin{array}{l}-0.0103^{* * *} \\
(0.00322)\end{array}$ & $\begin{array}{l}0.0327^{* * *} \\
(0.00845)\end{array}$ & $\begin{array}{l}-0.0191^{* *} \\
(0.00803)\end{array}$ & $\begin{array}{l}0.00364 \\
(0.0115)\end{array}$ \\
\hline Internal remittances & $\begin{array}{c}0.0167 \\
(0.0114)\end{array}$ & $\begin{array}{l}-0.00512 \\
(0.0106)\end{array}$ & $\begin{array}{l}-0.0164^{\star *} \\
(0.00827)\end{array}$ & $\begin{array}{c}0.00289 \\
(0.00437)\end{array}$ & $\begin{array}{c}0.00681 \\
(0.00429)\end{array}$ & $\begin{array}{c}0.00585 \\
(0.00651)\end{array}$ & $\begin{array}{c}-0.0102 \\
(0.00863)\end{array}$ \\
\hline International remittances & $\begin{array}{c}-0.0425^{\star * *} \\
(0.0101)\end{array}$ & $\begin{array}{l}0.0247^{\star *} \\
(0.0101)\end{array}$ & $\begin{array}{c}0.00123 \\
(0.00917)\end{array}$ & $\begin{array}{l}0.0106^{\star *} \\
(0.00534)\end{array}$ & $\begin{array}{l}0.0172^{\star \star \star} \\
(0.00497)\end{array}$ & $\begin{array}{c}0.00300 \\
(0.00581)\end{array}$ & $\begin{array}{l}-0.0137^{*} \\
(0.00801)\end{array}$ \\
\hline Internal \& Int'I remittances & $\begin{array}{l}-0.0145 \\
(0.0153)\end{array}$ & $\begin{array}{l}-0.00428 \\
(0.0138)\end{array}$ & $\begin{array}{c}4.00 \mathrm{e}-05 \\
(0.0102)\end{array}$ & $\begin{array}{c}0.00680 \\
(0.00734)\end{array}$ & $\begin{array}{l}-0.00153 \\
(0.00566)\end{array}$ & $\begin{array}{l}0.0238^{* *} \\
(0.0108)\end{array}$ & $\begin{array}{l}-0.0100 \\
(0.0123)\end{array}$ \\
\hline Constant & $\begin{array}{l}0.297^{* * *} \\
(0.0485)\end{array}$ & $\begin{array}{l}0.333^{* * *} \\
(0.0460)\end{array}$ & $\begin{array}{l}0.173^{* * *} \\
(0.0410)\end{array}$ & $\begin{array}{l}0.0485^{\star *} \\
(0.0226)\end{array}$ & $\begin{array}{l}0.00584 \\
(0.0182)\end{array}$ & $\begin{array}{c}0.0258 \\
(0.0269)\end{array}$ & $\begin{array}{l}0.116^{\star * *} \\
(0.0393)\end{array}$ \\
\hline $\begin{array}{l}\text { Observations } \\
\text { R-squared }\end{array}$ & $\begin{array}{l}1,939 \\
0.166\end{array}$ & $\begin{array}{l}1,939 \\
0.155\end{array}$ & $\begin{array}{l}1,939 \\
0.108\end{array}$ & $\begin{array}{l}1,939 \\
0.023\end{array}$ & $\begin{array}{l}1,939 \\
0.067\end{array}$ & $\begin{array}{l}1,939 \\
0.026\end{array}$ & $\begin{array}{l}1,939 \\
0.036\end{array}$ \\
\hline
\end{tabular}

Notes: (1) CD Goods is "consumed and durable" goods; Other includes expenditure on wedding, engagement, funerals;

(2) Robust standard errors in parentheses, ${ }^{* \star *} p<0.01,{ }^{* *} p<0.05,{ }^{*} p<0.1$ 
Table 9: OLS Estimates of Budget Share Equations - Working-Leser Model

\begin{tabular}{|c|c|c|c|c|c|c|c|}
\hline VARIABLES & $\begin{array}{c}(1) \\
\text { Food } \\
\end{array}$ & $\begin{array}{c}(2) \\
\text { CD goods } \\
\end{array}$ & $\begin{array}{c}(3) \\
\text { House\&land } \\
\end{array}$ & $\begin{array}{c}(4) \\
\text { Investment }\end{array}$ & $\begin{array}{c}(5) \\
\text { Education }\end{array}$ & $\begin{array}{c}(6) \\
\text { Health } \\
\end{array}$ & $\begin{array}{c}(7) \\
\text { Other } \\
\end{array}$ \\
\hline Log tot annual expenditure & $\begin{array}{l}-0.100^{\star * *} \\
(0.00602)\end{array}$ & $\begin{array}{l}0.000729 \\
(0.00619)\end{array}$ & $\begin{array}{l}0.0574^{\star * \star} \\
(0.00632)\end{array}$ & $\begin{array}{l}0.00678^{*} \\
(0.00384)\end{array}$ & $\begin{array}{c}1.79 e-05 \\
(0.00247)\end{array}$ & $\begin{array}{l}0.0108^{* \star *} \\
(0.00410)\end{array}$ & $\begin{array}{l}0.0251^{* * *} \\
(0.00497)\end{array}$ \\
\hline Household size & $\begin{array}{l}0.00416^{* * *} \\
(0.000829)\end{array}$ & $\begin{array}{c}0.000958 \\
(0.000876)\end{array}$ & $\begin{array}{c}-0.00553^{* * *} \\
(0.000787)\end{array}$ & $\begin{array}{l}-0.000597 \\
(0.000437)\end{array}$ & $\begin{array}{c}0.000369 \\
(0.000347)\end{array}$ & $\begin{array}{l}-0.000909^{*} \\
(0.000491)\end{array}$ & $\begin{array}{c}0.00155^{\star} \\
(0.000883)\end{array}$ \\
\hline Prop of children $(0-4)$ & $\begin{array}{l}0.0675^{\star *} \\
(0.0322)\end{array}$ & $\begin{array}{l}-0.101^{* * *} \\
(0.0334)\end{array}$ & $\begin{array}{l}-0.0188 \\
(0.0304)\end{array}$ & $\begin{array}{c}-0.00226 \\
(0.0138)\end{array}$ & $\begin{array}{c}-0.0399^{* * *} \\
(0.0130)\end{array}$ & $\begin{array}{l}0.0369^{* *} \\
(0.0186)\end{array}$ & $\begin{array}{l}0.0612^{* *} \\
(0.0271)\end{array}$ \\
\hline Prop of children $(5-15)$ & $\begin{array}{c}0.0846^{\star \star *} \\
(0.0271)\end{array}$ & $\begin{array}{c}-0.0954^{* \star *} \\
(0.0277)\end{array}$ & $\begin{array}{l}-0.0495^{*} \\
(0.0256)\end{array}$ & $\begin{array}{c}0.0124 \\
(0.0114)\end{array}$ & $\begin{array}{l}0.0583^{* * *} \\
(0.0111)\end{array}$ & $\begin{array}{l}0.00213 \\
(0.0149)\end{array}$ & $\begin{array}{c}-0.00968 \\
(0.0213)\end{array}$ \\
\hline Prop of elderly (>62) & $\begin{array}{l}-0.0281 \\
(0.0547)\end{array}$ & $\begin{array}{l}0.113^{* *} \\
(0.0547)\end{array}$ & $\begin{array}{l}-0.107^{* * *} \\
(0.0285)\end{array}$ & $\begin{array}{l}-0.00412 \\
(0.0131)\end{array}$ & $\begin{array}{c}-0.0469^{* * *} \\
(0.0144)\end{array}$ & $\begin{array}{c}0.0532 \\
(0.0324)\end{array}$ & $\begin{array}{c}0.0238 \\
(0.0335)\end{array}$ \\
\hline Prop of women (>15) & $\begin{array}{c}0.0404 \\
(0.0286)\end{array}$ & $\begin{array}{c}0.0294 \\
(0.0312)\end{array}$ & $\begin{array}{c}-0.0848^{* * *} \\
(0.0293)\end{array}$ & $\begin{array}{l}-0.00658 \\
(0.0114)\end{array}$ & $\begin{array}{l}-0.00486 \\
(0.0118)\end{array}$ & $\begin{array}{c}0.0177 \\
(0.0163)\end{array}$ & $\begin{array}{c}0.0142 \\
(0.0245)\end{array}$ \\
\hline Owning agriculture land & $\begin{array}{l}0.0176^{\star *} \\
(0.00843)\end{array}$ & $\begin{array}{l}-0.0912^{* * *} \\
(0.00869)\end{array}$ & $\begin{array}{l}-0.00270 \\
(0.00659)\end{array}$ & $\begin{array}{l}0.0164^{\star * *} \\
(0.00337)\end{array}$ & $\begin{array}{l}-0.00392 \\
(0.00359)\end{array}$ & $\begin{array}{l}0.0180^{\star * *} \\
(0.00520)\end{array}$ & $\begin{array}{l}0.0462^{\star * *} \\
(0.00735)\end{array}$ \\
\hline HH head ( =female) & $\begin{array}{c}0.0478 \\
(0.0313)\end{array}$ & $\begin{array}{l}-0.0229 \\
(0.0319)\end{array}$ & $\begin{array}{c}-0.00367 \\
(0.0256)\end{array}$ & $\begin{array}{c}-0.0274^{\star \star} \\
(0.0119)\end{array}$ & $\begin{array}{l}0.00794 \\
(0.0139)\end{array}$ & $\begin{array}{c}0.0148 \\
(0.0203)\end{array}$ & $\begin{array}{l}-0.0193 \\
(0.0265)\end{array}$ \\
\hline Age of the $\mathrm{HH}$ head & $\begin{array}{c}0.00150^{*} \\
(0.000807)\end{array}$ & $\begin{array}{l}-0.000636 \\
(0.000822)\end{array}$ & $\begin{array}{l}-0.000771 \\
(0.000623)\end{array}$ & $\begin{array}{l}-0.000453 \\
(0.000370)\end{array}$ & $\begin{array}{c}0.000496 \\
(0.000336)\end{array}$ & $\begin{array}{c}0.000797 \\
(0.000508)\end{array}$ & $\begin{array}{l}-0.001000 \\
(0.000673)\end{array}$ \\
\hline $\mathrm{HH}$ headªge & $\begin{array}{l}-0.000940^{*} \\
(0.000561)\end{array}$ & $\begin{array}{c}0.00100^{*} \\
(0.000587)\end{array}$ & $\begin{array}{c}-6.20 e-05 \\
(0.000434)\end{array}$ & $\begin{array}{c}0.000266 \\
(0.000194)\end{array}$ & $\begin{array}{l}-0.000152 \\
(0.000253)\end{array}$ & $\begin{array}{c}-0.000501 \\
(0.000364)\end{array}$ & $\begin{array}{c}0.000429 \\
(0.000464)\end{array}$ \\
\hline $\mathrm{HH}$ head with secondary educ & $\begin{array}{c}-0.0478^{* * *} \\
(0.00936)\end{array}$ & $\begin{array}{c}0.0186 \\
(0.0113)\end{array}$ & $\begin{array}{c}0.0101 \\
(0.0116)\end{array}$ & $\begin{array}{c}-0.00384 \\
(0.00394)\end{array}$ & $\begin{array}{l}0.0261^{\star * \star} \\
(0.00582)\end{array}$ & $\begin{array}{c}0.00306 \\
(0.00776)\end{array}$ & $\begin{array}{l}-0.00765 \\
(0.00895)\end{array}$ \\
\hline $\mathrm{HH}$ head with tertiary educ & $\begin{array}{c}-0.0457^{* * *} \\
(0.0129)\end{array}$ & $\begin{array}{l}0.0434^{* *} \\
(0.0170)\end{array}$ & $\begin{array}{l}0.0340^{\star} \\
(0.0191)\end{array}$ & $\begin{array}{l}-0.0169^{* * *} \\
(0.00584)\end{array}$ & $\begin{array}{l}0.0327^{* * *} \\
(0.00837)\end{array}$ & $\begin{array}{l}-0.0297^{* * *} \\
(0.00981)\end{array}$ & $\begin{array}{l}-0.0210^{*} \\
(0.0122)\end{array}$ \\
\hline Internal remittances & $\begin{array}{c}0.0148 \\
(0.0106)\end{array}$ & $\begin{array}{l}-0.00511 \\
(0.0106)\end{array}$ & $\begin{array}{l}-0.0153^{*} \\
(0.00798)\end{array}$ & $\begin{array}{c}0.00301 \\
(0.00438)\end{array}$ & $\begin{array}{c}0.00681 \\
(0.00430)\end{array}$ & $\begin{array}{c}0.00605 \\
(0.00647)\end{array}$ & $\begin{array}{l}-0.00973 \\
(0.00853)\end{array}$ \\
\hline International remittances & $\begin{array}{l}-0.00686 \\
(0.00918)\end{array}$ & $\begin{array}{l}0.0245^{\star *} \\
(0.0101)\end{array}$ & $\begin{array}{l}-0.0192^{* *} \\
(0.00871)\end{array}$ & $\begin{array}{c}0.00818 \\
(0.00506)\end{array}$ & $\begin{array}{l}0.0172^{* * *} \\
(0.00497)\end{array}$ & $\begin{array}{l}-0.000826 \\
(0.00618)\end{array}$ & $\begin{array}{c}-0.0227^{\star \star \star *} \\
(0.00819)\end{array}$ \\
\hline Internal \& Int'I remittances & $\begin{array}{c}0.0159 \\
(0.0130)\end{array}$ & $\begin{array}{l}-0.00450 \\
(0.0138)\end{array}$ & $\begin{array}{c}-0.0173^{\star} \\
(0.00979)\end{array}$ & $\begin{array}{c}0.00475 \\
(0.00686)\end{array}$ & $\begin{array}{l}-0.00154 \\
(0.00570)\end{array}$ & $\begin{array}{l}0.0206^{*} \\
(0.0107)\end{array}$ & $\begin{array}{l}-0.0176 \\
(0.0121)\end{array}$ \\
\hline Constant & $\begin{array}{l}1.685^{\star * *} \\
(0.0991)\end{array}$ & $\begin{array}{l}0.323^{* * *} \\
(0.0974)\end{array}$ & $\begin{array}{l}-0.620^{* * *} \\
(0.0948)\end{array}$ & $\begin{array}{l}-0.0452 \\
(0.0453)\end{array}$ & $\begin{array}{l}0.00559 \\
(0.0434)\end{array}$ & $\begin{array}{l}-0.123^{*} \\
(0.0646)\end{array}$ & $\begin{array}{l}-0.231^{* * *} \\
(0.0787)\end{array}$ \\
\hline $\begin{array}{l}\text { Observations } \\
\text { R-squared }\end{array}$ & $\begin{array}{l}1,939 \\
0.314 \\
\end{array}$ & $\begin{array}{l}1,939 \\
0.155 \\
\end{array}$ & $\begin{array}{l}1,939 \\
0.185 \\
\end{array}$ & $\begin{array}{l}1,939 \\
0.027 \\
\end{array}$ & $\begin{array}{l}1,939 \\
0.067 \\
\end{array}$ & $\begin{array}{l}1,939 \\
0.032 \\
\end{array}$ & $\begin{array}{l}1,939 \\
0.053 \\
\end{array}$ \\
\hline
\end{tabular}

Notes: (1) CD Goods is "consumed and durable" goods; Other includes expenditure on wedding, engagement, funerals;

(2) Robust standard errors in parentheses, ${ }^{* * *} p<0.01$, ${ }^{* *} p<0.05,{ }^{*} p<0.1$ 
Table 10 - Marginal Budget Shares and Expenditure Elasticities

Food CD goods House\&land Investment Educ Health Others

\begin{tabular}{llllllll}
\hline $\begin{array}{l}\text { Marginal } \\
\text { budget share }\end{array}$ & 0.263 & 0.302 & 0.124 & 0.022 & 0.050 & 0.0878 & 0.147 \\
Elasticity & 0.724 & 1.002 & 1.848 & 1.430 & 1.000 & 1.139 & 1.204
\end{tabular}

Note: (1) CD Goods is "consumed and durable" goods; Other includes expenditure on wedding, engagement, funerals;

(2) The marginal budget shares and elasticities are derived from the estimated coefficients reported on Table 9.

\section{Table 11 - Estimates of Budget Share Equations with Interaction Terms}

\begin{tabular}{|c|c|c|c|c|c|c|c|}
\hline VARIABLES & Food & CD goods & $\begin{array}{l}\text { House \& } \\
\text { Land }\end{array}$ & Investment & Education & Health & Other \\
\hline log_tot_exp & $\begin{array}{l}-0.091^{\star * \star} \\
(-10.70)\end{array}$ & $\begin{array}{l}-0.00088 \\
(-0.115)\end{array}$ & $\begin{array}{l}0.051^{* \star *} \\
(6.936)\end{array}$ & $\begin{array}{l}0.0040 \\
(1.040)\end{array}$ & $\begin{array}{l}-0.0013 \\
(-0.425)\end{array}$ & $\begin{array}{l}0.012^{\star \star} \\
(2.349)\end{array}$ & $\begin{array}{l}0.025^{\star \star \star} \\
(4.013)\end{array}$ \\
\hline $\log (\exp )^{\star}$ internal remittances & $\begin{array}{l}-0.029^{* *} \\
(-2.047)\end{array}$ & $\begin{array}{l}0.015 \\
(1.059)\end{array}$ & $\begin{array}{l}0.0036 \\
(0.265)\end{array}$ & $\begin{array}{l}-0.0047 \\
(-0.898)\end{array}$ & $\begin{array}{l}0.0017 \\
(0.336)\end{array}$ & $\begin{array}{l}0.00040 \\
(0.0438)\end{array}$ & $\begin{array}{l}0.012 \\
(0.962)\end{array}$ \\
\hline $\begin{array}{l}\text { Log }(\text { expenditure })^{*} \text { international } \\
\text { remittances }\end{array}$ & -0.00529 & -0.00764 & 0.0159 & 0.00643 & 0.00625 & -0.00650 & -0.00967 \\
\hline \multirow{2}{*}{$\begin{array}{l}\log (\exp )^{*} \text { internal\& } \\
\text { international remittances }\end{array}$} & $\begin{array}{l}(-0.466) \\
-0.049^{* \star *}\end{array}$ & $\begin{array}{l}(-0.623) \\
0.019\end{array}$ & $\begin{array}{l}(1.176) \\
0.012\end{array}$ & $\begin{array}{l}(0.748) \\
0.017\end{array}$ & $\begin{array}{l}(0.887) \\
-0.0043\end{array}$ & $\begin{array}{l}(-1.008) \\
-0.0022\end{array}$ & $\begin{array}{l}(-1.023) \\
0.0058\end{array}$ \\
\hline & $(-3.035)$ & $(0.984)$ & $(0.819)$ & $(1.498)$ & $(-0.762)$ & $(-0.156)$ & $(0.370)$ \\
\hline Observations & 1,939 & 1,939 & 1,939 & 1,939 & 1,939 & 1,939 & 1,939 \\
\hline R-squared & 0.319 & 0.157 & 0.187 & 0.032 & 0.069 & 0.033 & 0.055 \\
\hline
\end{tabular}

Notes: (1) CD Goods is "consumed and durable" goods; Other includes expenditure on wedding, engagement, funerals;

(2) This table reports only the OLS coefficients for the log of total expenditure and its interaction with the remittance statuses. The other coefficients of equation 12 are omitted from the table;

(3) Robust standard errors in parentheses, ${ }^{* \star} p<0.01,{ }^{* *} p<0.05,{ }^{\star} p<0.1$ 
Table 12: Marginal budget shares and elasticities

Food CD goods House\&land Investment Education Health Other

\begin{tabular}{cccccccc}
\hline $\begin{array}{c}\text { Marginal budget share } \\
\text { - No remittances }\end{array}$ & 0.263 & 0.300 & 0.124 & 0.197 & 0.049 & 0.089 & 0.148 \\
$\begin{array}{c}\text { Marginal budget share } \\
- \text { Internal remittances }\end{array}$ & 0.243 & 0.316 & 0.122 & 0.014 & 0.050 & 0.090 & 0.161 \\
$\begin{array}{c}\text { Marginal budget share- } \\
\text { International } \\
\text { remittances }\end{array}$ & 0.267 & 0.293 & 0.135 & 0.261 & 0.055 & 0.083 & 0.138 \\
$\begin{array}{c}\text { Marginal budget share- } \\
\text { Internal \& Int'l } \\
\text { remittances }\end{array}$ & 0.224 & 0.320 & 0.131 & 0.037 & 0.044 & 0.087 & 0.154 \\
\hline $\begin{array}{c}\text { Elasticity - No } \\
\text { remittances }\end{array}$ & 0.724 & 0.997 & 1.764 & 1.255 & 0.972 & 1.163 & 1.208 \\
$\begin{array}{c}\text { Elasticity - Internal } \\
\text { remittances }\end{array}$ & 0.669 & 1.04 & 1.818 & 0.951 & 1.006 & 1.168 & 1.312 \\
$\begin{array}{c}\text { Elasticity- International } \\
\text { remittances }\end{array}$ & 0.735 & 0.971 & 2.000 & 1.663 & 1.096 & 1.079 & 1.129 \\
$\quad \begin{array}{l}\text { Elasticity - Internal } \\
\text { \&Int'I remittances }\end{array}$ & 0.615 & 1.061 & 1.95 & 2.37 & 0.887 & 1.134 & 1.129 \\
\hline Note: (1) CD Goods is "consumed and durable" goods; Other includes expenditure on wedding, engagement, funerals; &
\end{tabular}

Table 11.
Therals;

(2) The marginal budget shares and elasticities are derived from the estimated coefficients reported in Table 11. 